\title{
Essential relationships incorporating the influence of age, size and condition on variables required for estimation of reproductive potential in Atlantic cod Gadus morhua
}

\author{
Gudrun Marteinsdottir ${ }^{1,2, *}$, Gavin A. Begg ${ }^{2, * *}$
}

${ }^{1}$ University of Iceland, Institute of Biology, and ${ }^{2}$ Marine Research Institute; Skulagata 4, PO Box 1390, 121 Reykjavik, Iceland

\begin{abstract}
Evidence accumulated over the last decade indicates that reproductive potential of marine fish stocks is not correctly represented by spawning stock biomass. Fundamental variables that affect reproductive potential of fish stocks (i.e. proportion mature at age, fecundity, and offspring size and viability) have found to vary with age, size, and condition of spawning fish, and/or spawning experience. Modeling initiatives that attempt to describe reproductive potential by incorporating all available information on reproductive variables require extensive, high quality data of a temporal and spatial origin. In this study, we explored the influence of female age, size, and condition on several reproductive variables for the cod Gadus morhua, including maturity, fecundity, egg density and size, and larval size and growth. In addition, we described the potential for annual variation in these relationships to increase our knowledge of temporal stability for fundamental variables that influence reproductive potential.
\end{abstract}

KEY WORDS: Cod $\cdot$ Maturity $\cdot$ Fecundity $\cdot$ Egg size $\cdot$ Larval size $\cdot$ Stock-recruitment $\cdot$ Population dynamics $\cdot$ Fisheries management

Resale or republication not permitted without written consent of the publisher

\section{INTRODUCTION}

Reproductive potential represents the ability of a fish stock to produce viable offspring that may recruit to the adult population or fishery (Trippel 1999), incorporating individual and stock effects of its spawning components. Traditionally, spawning stock biomass (SSB) has been used in stock-recruitment models as a proxy for reproductive potential, with the implicit assumption of proportionality between total egg production (i.e. reproductive potential) and SSB (Trippel et al. 1997a, Marshall et al. 1998). However, during the past decade an increasing number of studies have demonstrated that SSB is not an accurate measure of reproductive

\footnotetext{
*E-mail: runa@hafro.is

${ }^{* *}$ Present address: CRC Reef Research Centre, James Cook University, Townsville, Queensland 4811, Australia
}

potential, with serious flaws in the assumed proportionality between the 2 measures (Trippel et al. 1997a, Marshall et al. 1998, Marteinsdottir \& Thorarinsson 1998, Scott et al. 1999). Fundamental variables that affect reproductive potential of fish stocks (i.e. proportion mature at age, fecundity, and offspring size and viability) have found to vary with age, size, and condition of spawning fish, and/or spawning experience (Stearns \& Crandall 1984, Jørgensen 1990, Kjesbu et al. 1991, Solemdal et al. 1995, MacKenzie et al. 1998, Marshall et al. 1998, Marteinsdottir \& Steinarsson 1998, Trippel 1998). Moreover, accumulating information on maternal effects has stimulated modelers to re-estimate reproductive potential by incorporating reproductive variables that influence total egg production (Marshall et al. 1998, 1999, Murawski et al. 1999, Scott et al. 1999, Cardinale \& Arrhenius 2000a,b, Marteinsdottir et al. 2000a). Based on these modeling 
initiatives, re-examination of stock-recruitment relationships may provide new information on how the composition of a spawning stock influences recruitment (Marteinsdottir \& Thorarinsson 1998). However, to create new biological reference points based on stock-recruitment relationships, such modeling initiatives require extensive data on the influence of maternal effects on reproductive potential (Trippel 1999), particularly time series data on age, size and condition of spawners (Marshall et al. 2000).

In Atlantic cod Gadus morhua, relationships between some fundamental reproductive variables and age, size and condition of spawners have been well documented. For example, the maternal effects of age, size and condition on size, growth and viability of eggs and larvae have been widely studied (Knutsen \& Tilseth 1985, Kjesbu 1989, Solemdal et al. 1992, 1995, Chambers \& Waiwood 1996, Chambers 1997, Solemdal 1997, Trippel et al. 1997a, Marteinsdottir \& Steinarsson 1998). Furthermore, relationships between potential fecundity and female age and/or size have been documented for many cod populations (May 1967, Schopka 1971, Pinhorn 1984, Kjesbu et al. 1998, Marteinsdottir et al. 2000a). However, fewer studies have attempted to document the influence of spawners' condition on fecundity, and relationships based on relative fecundity of cod populations are scarce (Kjesbu et al. 1998). Considering the great importance of these relationships and the influence they have on final estimates of total egg production, and hence reproductive potential, there is an obvious need for more data and a greater understanding of the spatial and temporal variation in potential and relative fecundity. Similarly, while information on age and/or length at maturity is routinely collected for stock assessment purposes, fundamental relationships on the effects of condition on maturity are also scarce.

Data that exist on the influence of maternal effects on reproductive variables are often based on observations from restricted time-series that do not allow analysis of temporal stability of these variables. Kjesbu et al. (1998) have questioned the underlying assumption of constant relative fecundity that is presently used in recruitment studies, after demonstrating environmentally induced variation in both potential and relative fecundity of Arcto-Norwegian cod due to annual changes in its food source. Similarly, environmental conditions are likely to influence not only the amplitude of egg production, but also the time of maturation, and the quality of production reflected in egg and larval sizes and survival (Cardinale \& Arrhenius 2000a, Vallin \& Nissling 2000). However, uncoupling the influence of environmental and biotic conditions on reproductive life history characteristics is difficult, particularly given the magnitude of fishery-induced changes that have typically occurred on most exploited cod stocks (Serchuk et al. 1994).

In this study, we explored the influence of age, size and condition of cod on reproductive variables, including maturity, fecundity, egg density and size, and larval size and growth. Essential relationships based on these variables were derived to provide modellers with the necessary information required for re-estimation of more accurate measures of reproductive potential. In addition, we described the potential for annual variation in these relationships to increase our knowledge of temporal stability for the fundamental variables that influence reproductive potential. These relationships were placed in the context of those for other cod populations in the north Atlantic to determine their spatial consistency, while providing a comprehensive basis for future modeling initiatives re-examining stockrecruitment relationships.

\section{MATERIALS AND METHODS}

Maturity. Data on age and size at maturity of cod were obtained from the annual (1985 to 1999) Icelandic spring groundfish surveys. These surveys were conducted each year for 2 to 3 wk in March coinciding with the beginning of the spawning season for cod (Pálsson et al. 1989). More than 250 stations were sampled each year, providing a complete coverage of the geographical area (Fig. 1) occupied by cod on the continental shelf around Iceland (Pálsson et al. 1989). At each station, most cod were measured $(\mathrm{cm})$, and sex and maturity stage (1: immature; 2: ripening; 3: spawning; or 4: spent) determined macroscopically (following the stages defined in Powles 1958). Otoliths were removed from all weighted fish, and in the laboratory, 1 otolith from each pair was sectioned and assigned an age following standard methods (Pentilla \& Dery 1988).

A total of $52243 \mathrm{cod}$ were included in the maturity data analysis, of which 34608 were immature and 17635 mature (Table 1). The data were divided geographically into northern and southern statistical

Table 1. Number of mature and immature cod sampled during the Icelandic spring groundfish surveys (1985 to 1999) in the northern and southern statistical regions used in the maturity analysis

\begin{tabular}{|lrcrrr|}
\hline Region & Immature & $\begin{array}{c}\text { Mature } \\
\text { females }\end{array}$ & $\begin{array}{c}\text { Mature } \\
\text { males }\end{array}$ & $\begin{array}{c}\text { Total } \\
\text { mature }\end{array}$ & Total \\
\hline North & 26757 & 3200 & 3378 & 6578 & 33335 \\
South & 7851 & 4838 & 6219 & 11057 & 18908 \\
Total & 34608 & 8038 & 9597 & 17635 & 52243 \\
\hline
\end{tabular}




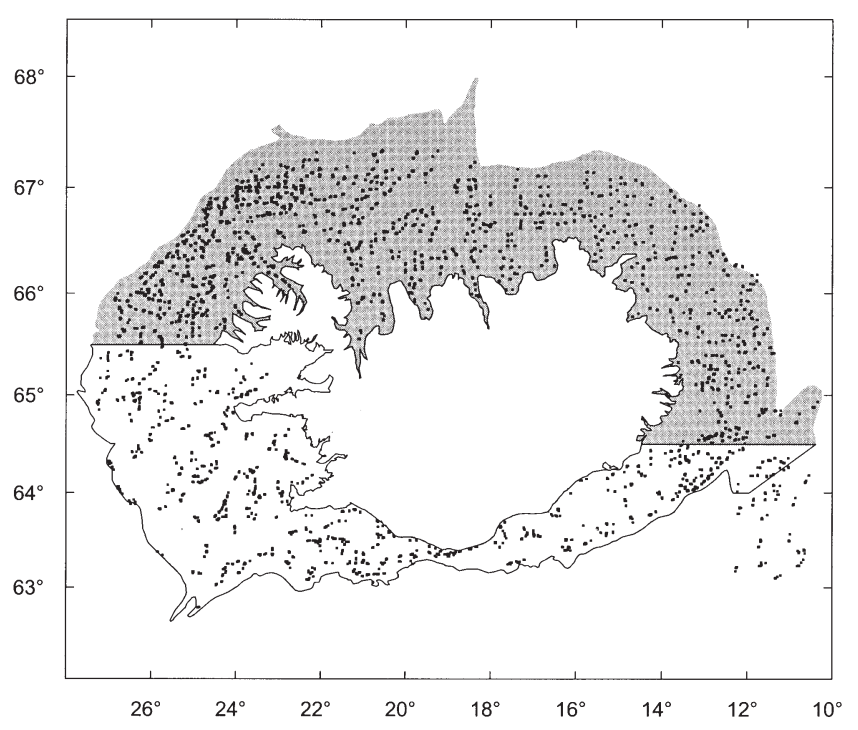

Fig. 1. Station locations of Icelandic spring groundfish surveys (1985 to 1999) for the northern and southern statistical regions. The outer boundary designates the $500 \mathrm{~m}$ depth contour

regions based on hydrographical and ecological differences (Begg \& Marteinsdottir 2002a; their Fig. 1), where the waters in the northern region were generally colder and more variable than those in the southern region (Malmberg \& Kristmannsson 1992).

Fecundity. Potential fecundity (PF) and relative fecundity (RF) were estimated for cod females collected each year (1995 to 2000) several weeks (January to February) prior to the spawning season (March to May) from the main spawning grounds off the southwest coast of Iceland (Fig. 1). Potential fecundity is the total number of developing (or vitellogenic) oocytes in the ovary that can potentially be released, while relative fecundity is a measure of potential fecundity per unit of body weight (Kjesbu et al. 1998, Marshall et al. 1998). Total length, whole body weight and gonad and liver weights of each female were measured and used to calculate indices of Somatic condition $(K)$ and hepatosomatic condition $(H)$. In order to maintain consistency with other studies (i.e. Kjesbu et al. 1991, 1998), estimates of $K$ were based on whole body weight and $H$ on ovarian free body weight according to the following equations:

$$
\begin{gathered}
K=\frac{W}{L^{3}} \times 100 \\
H=\frac{\mathrm{LW}}{(W-\mathrm{OW})} \times 100
\end{gathered}
$$

where $W=$ whole body weight $(\mathrm{g}) ; L=$ total length $(\mathrm{cm}) ; \mathrm{LW}=$ liver weight $(\mathrm{g})$; and OW = ovary weight $(\mathrm{g})$.
Potential fecundity estimates were then determined gravimetrically from counts of oocytes in weighed portions (0.3 g) of ovary tissue. A total of 869 female cod were analyzed during this period, where different methods of oocyte preservation were used. In 1995, ovary sections were digested in Gilson fluid for 3 mo and then transferred to $4 \%$ buffered formalin. In 1996 and 1997, ovary sections were digested in $2 \mathrm{ml}$ of buffered enzyme solution (2 mg Collagenase D from Boehringer Cat.\#:1088866 dissolved in $2 \mathrm{ml} 0.1 \mathrm{M}$ Tris/5 mM CaCl 2 pH 7.6 for 120 min, which dissolved the collagen in the connective tissue but left the oocytes intact; G. Steingrimsdottir \& G. Petursdottir unpubl.) and then transferred to $4 \%$ formaldehyde. In 1998, 1999 and 2000, oocytes were separated from ovary sections by rapid shaking (Thermolyne Vortex Shaker E-51805-00, Cole Parmer Instumental) in 4\% buffered formalin for 1 to $2 \mathrm{~min}$. If the ovary section could not be treated immediately after sampling, the sections were stored in their ovarian fluid in a refrigerator $\left(\sim 4^{\circ} \mathrm{C}\right)$ for no more than $12 \mathrm{~h}$. Following all methods of preservation, a sub-sample of vitellogenic oocytes from each section was then counted with the aid of an image analyzer (Optimas 5.2 or Leica Q500) attached to a dissecting microscope, using $6 \times$ magnification. Each image was compared visually with the sub-sample under the microscope and checked for accuracy of oocyte detection. RF of each cod was then estimated according to the following equation:

$$
\mathrm{RF}=\frac{\mathrm{PF}}{W}
$$

where PF = potential fecundity (millions vitellogenic oocytes).

Batch fecundity (BF) was estimated for 200 spawning cod collected in 1999 during the spawning season from the main spawning grounds off the southwest coast of Iceland. Batch fecundity is the number of hyaline or ovulated oocytes in the ovary due to be spawned in the immediate future (Kjesbu et al. 1998). Batch fecundity estimates were determined from weighed sub-samples $(0.16$ to $0.18 \mathrm{~g})$ of ovarian tissue, preserved in $4 \%$ phosphate buffered formalin. Batch size estimates were then determined from the total number of hydrated oocytes counted in the ovary sub-sample. The total number of vitellogenic oocytes was also counted and compared to the estimated potential fecundity (EPF) for each sample to provide an indication of spawning status (proportion of oocytes left in the ovary in relation to EPF ). EPF was derived from the 1999 relationship between $P F$ and $L$.

Egg and larvae. During the spawning season of 1994, 1995 and 1996, freely running eggs were stripped from a total of 79, 86 and 69 female cod, respectively, on the main spawning grounds off the SW coast of Iceland. 
Eggs were stripped from female cod during several cruises throughout the spawning season and fertilized in vitro. $L$ and $W$, LW and ovary weight of each female were also measured, and their otoliths removed. Eggs were maintained at 6 to $7^{\circ} \mathrm{C}$, and transported to the laboratory within 2 to $3 \mathrm{~d}$ of sampling. In 1994 and 1996, females were classified into 4 spawning stages (SPS), based on mean and standard deviation of vitellogenic oocytes present in the ovary at each time (Kjesbu et al. 1990, Marteinsdottir \& Steinarsson 1998): I: $<30 \%$; II: 30 to $50 \%$; III: 55 to $80 \%$; and IV: $>80 \%$ of eggs spawned. In the laboratory, egg diameters (ED), and egg dry and wet weights were obtained following the methods in Marteinsdottir \& Steinarsson (1998). Egg batches were reared in individual containers at $7^{\circ} \mathrm{C}$. In 1996, absolute density $\left(\mathrm{g} \mathrm{cm}^{-3}\right)$ of 20 eggs from each batch were sampled $5 \mathrm{~d}$ after fertilization and measured in a density gradient column (Martin Instruments) following the methods in Coombs (1981). A fresh salinity gradient was prepared each day using UV-filtered sea water, de-ionized fresh water and $\mathrm{NaCl}$. Temperature was held constant at 7 to $7.3^{\circ} \mathrm{C}$ during all density measurements and all density data were converted to $7^{\circ} \mathrm{C}$.

At hatching, larvae were sampled for initial length measurements within a few hours of first hatch (Marteinsdottir \& Steinarsson 1998). Length measurements $(\mathrm{mm})$ were obtained for 20 larvae from each batch, with the aid of an image analyzer (Leica Q500) attached to a binocular microscope, using $25 \times$ magnification. Additional samples of 20 larvae were taken from each batch for measurements of wet weight (only in 1994) and dry weight (all years). Larvae from 45, 35 and 60 egg batches in 1994, 1995 and 1996, respectively, were retained for rearing and growth experiments. Experiments were terminated after 20 d. Daily $\left(\mathrm{DGR}, \mathrm{mg} \mathrm{d}^{-1}\right.$ ) and specific growth rates $\left(\mathrm{SGR}, \% \mathrm{~d}^{-1}\right)$ of each larvae were then estimated according to the following equations:

$$
\begin{aligned}
\mathrm{DGR} & =\frac{\log _{\mathrm{e}} W_{t_{2}}-\log _{\mathrm{e}} W_{t_{1}}}{t_{2}-t_{1}} \\
\mathrm{SGR} & =\left(\mathrm{e}^{\mathrm{DGR}}-1\right) \times 100
\end{aligned}
$$

where $W=$ body weight $(\mathrm{mg}) ; t_{1}=$ time at hatching (Day 0 ) and $t_{2}=$ time when the experiment was terminated (Day 20). For further details see Marteinsdottir \& Steinarsson (1998).

Statistical analysis. Logistic regression analysis (Sokal \& Rohlf 1995) was used to estimate maturity ogives (immature: Stage 1 ; mature: Stages 2 to 4 ) to determine length $\left(L_{50}\right)$ and age $\left(A_{50}\right)$ at $50 \%$ maturity for female and male cod in each statistical region (North, South) and year (1985 to 1999). Scheffé multiple comparison tests (MathSoft 1998) were used to compare maturity ogives between sexes, and condition groups of each sex in each region. Generalized linear models (GLM, binomial distribution) were then used to examine the influence of length, age and condition on maturity. An additional measure of model fit was based on a pseudo-coefficient of determination $\left(\mathrm{R}^{2}\right)$, which was the fraction of the total 'variation' explained by the model

$$
\mathrm{R}^{2}=1-\left\lfloor\frac{\text { Residual deviance }}{\text { Null deviance }}\right\rfloor
$$

where deviance was analagous to the residual sums of squares (Swartzman et al. 1995). Analysis of variance (ANOVA) on $\log _{\mathrm{e}}$-transformed data was used to compare length and condition among age groups of each sex in each region.

Fecundity relationships were compared with analysis of covariance (ANCOVA), while the influence of length and condition on relative fecundity was evaluated with a multiple regression.

Similarly, the effects of year, spawning stage and length on egg diameters were examined with multiple regression models. The same procedures were used to examine the relative influence of spawning stage, egg diameter, female size and condition on egg density.

\section{RESULTS}

\section{Maturity}

Sexual maturity ( $L_{50}$ and $A_{50}$ ) was found to differ on a spatial and temporal basis, both among and between female and male cod (Fig. 2, Table 2). Overall, throughout the survey period (1985 to 1999), $50 \%$ of female cod reached maturity at the mean length of $75.6 \mathrm{~cm}$ and mean age of $6.6 \mathrm{yr}$ (Table 2). In contrast, $50 \%$ of male cod reached maturity at $67.2 \mathrm{~cm}$ and $5.8 \mathrm{yr}$ (Table 2). Significant differences in maturity were found between cod in waters off the north and south coasts (Scheffé $F$-test, p < 0.05), as well as between sexes in each region (Scheffé $F$-test, $\mathrm{p}<0.05$; Fig. 2, Table 2). In the north, $50 \%$ of female cod reached maturity at $80.2 \mathrm{~cm}$ and $7.3 \mathrm{yr}$, while in the south $L_{50}$ and $A_{50}$ were $71.0 \mathrm{~cm}$ and $5.9 \mathrm{yr}$, respectively (Table 2). In contrast, $50 \%$ of male cod in the north reached maturity at $72.8 \mathrm{~cm}$ and $6.6 \mathrm{yr}$, while in the south $L_{50}$ and $A_{50}$ were $61.5 \mathrm{~cm}$ and $5.0 \mathrm{yr}$, respectively (Table 2).

The size and age at sexual maturity were also found to differ between years for cod in waters off the north and south coasts, with a general decline in both length and age at maturity observed throughout the survey period (Fig. 2). Sexual maturity of female cod in the north declined from $87.3 \mathrm{~cm}$ and $8.3 \mathrm{yr}$ in 1985 to $76.5 \mathrm{~cm}$ and $6.7 \mathrm{yr}$ in 1999 (Linear regressions, $L_{50}: \mathrm{r}^{2}=$ 
$\left.0.61, \mathrm{p}<0.001, A_{50}: \mathrm{r}^{2}=0.57, \mathrm{p}<0.001\right)$ and in the south from $77.4 \mathrm{~cm}$ and $6.5 \mathrm{yr}$ to $69.2 \mathrm{~cm}$ and $5.8 \mathrm{yr}$ (linear regressions omitting 1990 to $1991, L_{50}: \mathrm{r}^{2}=0.48, \mathrm{p}<$ $0.05, A_{50}: \mathrm{r}^{2}=0.34, \mathrm{p}<0.05$; Fig. 2). Similarly, although not as consistent, sexual maturity of male cod in the north declined from $73.5 \mathrm{~cm}$ and $6.8 \mathrm{yr}$ in 1985 to $70.0 \mathrm{~cm}$ and $6.4 \mathrm{yr}$ in 1999 (linear regressions, $L_{50}: \mathrm{r}^{2}=$ $\left.0.34, \mathrm{p}<0.05, A_{50}: \mathrm{r}^{2}=0.29, \mathrm{p}<0.05\right)$, and in the south from 66.9 to $59.4 \mathrm{~cm}$ (linear regression omitting 1990 to $1991, \mathrm{r}_{2}=0.45, \mathrm{p}<0.05$ ), while decline in $A_{50}$ from 5.4 to $4.8 \mathrm{yr}$ was not significant (linear regression omitting 1990 to $1991, r^{2}=0.15, p=0.198$; Fig. 2). The spatial disparity in maturity between cod in waters off the north and south coasts, where those in the north reached maturity at greater lengths and ages than those in the south, was most likely reflective of slower growth rate, influenced by colder water temperatures in the north (Fig. 3).

Size of mature and immature cod overlapped greatly (combined data 1985 to 1999), although generally within an age group the mean total length of mature cod was significantly greater than that of immature cod (ANOVA on ln-transformed total length, $\mathrm{p}<0.05$; Fig. 4). This was true for age groups 4 to 9 among sexes and regions, except 4 and 5 yr old males in the north. Similarly, somatic condition $(K)$ of mature and immature cod overlapped greatly, although within an age group the mean $K$ of mature cod was significantly greater than that of immature cod, except for 3 yr old females and males in both regions and for $4 \mathrm{yr}$ old females in the north (ANOVA, $p<0.05$; Fig. 4). Low sample sizes within the respective age, region, sex and maturity-stage were most likely responsible for the non-significant results detected in these analyses. Small sample sizes prevented the analysis of these data on an annual basis.

Both length and condition $(K)$ affected maturity when analysed within the same model $(\mathrm{p}<0.01$, Table 3). Moreover, on average, length accounted for a 16 -fold greater amount of the variation than that accounted for by $K$ (Table 3 ). Similar results were found for the effects of age and $K$ on maturity, where on average, age accounted for an 8-fold greater amount of variation than that accounted for by $K$ (Tables $2 \& 3$ ). Differences in $L_{50}$ of cod in the different condition classes (low: $K<0.8$; medium: $K=0.8$ to 1.0 ; high: $K>1.0$ ) were less distinct in the south than in the north (Fig. 5, Table 2). $L_{50}$ differed significantly between all condition classes of female and male cod in the north (Scheffé F-test, $\mathrm{p}<0.05$ ), while only lowcondition cod differed significantly from high- and medium-condition cod in the south (Scheffé $F$-test, $\mathrm{p}<$ 0.05 ; Fig. 5, Table 2). In contrast, $A_{50}$ differed significantly between all condition classes of female and male cod both in the north and in the south (Scheffé F-test, $\mathrm{p}<0.05$; Fig. 5, Table 2).

Table 2. Length $L_{50}(\mathrm{~cm} \pm \mathrm{SE})$ and age $A_{50}(\mathrm{yr} \pm \mathrm{SE})$ at $50 \%$ maturity for female and male cod in 3 condition $(K)$ classes $(K>1.0 ;$ $K=0.8$ to $1.0 ; \mathrm{K}<0.8$ ) in waters off the north and south coasts of Iceland ( $L_{50}$ and $A_{50}$ for all cod were obtained from the combined data 1983 to $1999 ; L_{50}$ and $A_{50}$ for condition groups were obtained from the combined data from 1985 to 1999 )

\begin{tabular}{|c|c|c|c|c|c|}
\hline Sex & Region & $\begin{array}{c}L_{50} \\
\text { all cod }\end{array}$ & $<0.8$ & $\begin{array}{c}\text { Condition }(K) \\
0.8-1.0\end{array}$ & $>1.0$ \\
\hline Females & $\begin{array}{l}\text { North } \\
\text { South } \\
\text { Total }\end{array}$ & $\begin{array}{l}80.2 \pm 0.31 \\
71.0 \pm 0.25 \\
75.6 \pm 0.18\end{array}$ & $\begin{array}{l}90.0 \pm 2.43 \\
75.5 \pm 0.84 \\
79.8 \pm 0.74\end{array}$ & $\begin{array}{l}77.0 \pm 0.52 \\
69.6 \pm 0.43 \\
73.4 \pm 0.35\end{array}$ & $\begin{array}{l}67.8 \pm 0.75 \\
68.7 \pm 0.83 \\
68.0 \pm 0.54\end{array}$ \\
\hline Males & $\begin{array}{l}\text { North } \\
\text { South } \\
\text { Total }\end{array}$ & $\begin{array}{l}72.8 \pm 0.29 \\
61.5 \pm 0.26 \\
67.2 \pm 0.16\end{array}$ & $\begin{array}{l}89.1 \pm 2.49 \\
69.1 \pm 0.77 \\
75.5 \pm 0.69\end{array}$ & $\begin{array}{l}69.8 \pm 0.43 \\
60.6 \pm 0.44 \\
65.7 \pm 0.25\end{array}$ & $\begin{array}{l}60.4 \pm 0.68 \\
57.9 \pm 0.98 \\
59.6 \pm 0.54\end{array}$ \\
\hline Both & $\begin{array}{l}\text { North } \\
\text { South } \\
\text { Total }\end{array}$ & $\begin{array}{l}77.0 \pm 0.22 \\
65.9 \pm 0.18 \\
71.4 \pm 0.12\end{array}$ & $\begin{array}{l}89.9 \pm 1.78 \\
72.4 \pm 0.59 \\
77.8 \pm 0.52\end{array}$ & $\begin{array}{l}73.7 \pm 0.31 \\
64.8 \pm 0.31 \\
69.5 \pm 0.20\end{array}$ & $\begin{array}{l}64.2 \pm 0.53 \\
62.8 \pm 0.66 \\
63.6 \pm 0.39\end{array}$ \\
\hline Sex & Region & $\begin{array}{c}A_{50} \\
\text { all cod }\end{array}$ & $<0.8$ & $\begin{array}{l}\text { Condition }(K) \\
0.8-1.0\end{array}$ & $>1.0$ \\
\hline Females & $\begin{array}{l}\text { North } \\
\text { South } \\
\text { Total }\end{array}$ & $\begin{array}{l}7.3 \pm 0.04 \\
5.9 \pm 0.02 \\
6.6 \pm 0.03\end{array}$ & $\begin{array}{l}9.7 \pm 0.45 \\
6.5 \pm 0.11 \\
7.6 \pm 0.13\end{array}$ & $\begin{array}{l}6.8 \pm 0.05 \\
5.7 \pm 0.03 \\
6.3 \pm 0.03\end{array}$ & $\begin{array}{l}5.8 \pm 0.07 \\
5.1 \pm 0.08 \\
5.5 \pm 0.05\end{array}$ \\
\hline Males & $\begin{array}{l}\text { North } \\
\text { South } \\
\text { Total }\end{array}$ & $\begin{array}{l}6.6 \pm 0.02 \\
5.0 \pm 0.03 \\
5.8 \pm 0.03\end{array}$ & $\begin{array}{l}9.6 \pm 0.47 \\
5.8 \pm 0.11 \\
7.2 \pm 0.12\end{array}$ & $\begin{array}{l}6.2 \pm 0.05 \\
5.0 \pm 0.05 \\
5.7 \pm 0.05\end{array}$ & $\begin{array}{l}5.1 \pm 0.07 \\
4.5 \pm 0.09 \\
4.9 \pm 0.05\end{array}$ \\
\hline Both & $\begin{array}{l}\text { North } \\
\text { South } \\
\text { Total }\end{array}$ & $\begin{array}{l}7.0 \pm 0.02 \\
5.4 \pm 0.02 \\
6.2 \pm 0.01\end{array}$ & $\begin{array}{l}9.6 \pm 0.33 \\
6.2 \pm 0.07 \\
7.4 \pm 0.09\end{array}$ & $\begin{array}{l}6.5 \pm 0.04 \\
5.4 \pm 0.03 \\
6.0 \pm 0.02\end{array}$ & $\begin{array}{l}5.5 \pm 0.05 \\
4.8 \pm 0.06 \\
5.2 \pm 0.03\end{array}$ \\
\hline
\end{tabular}



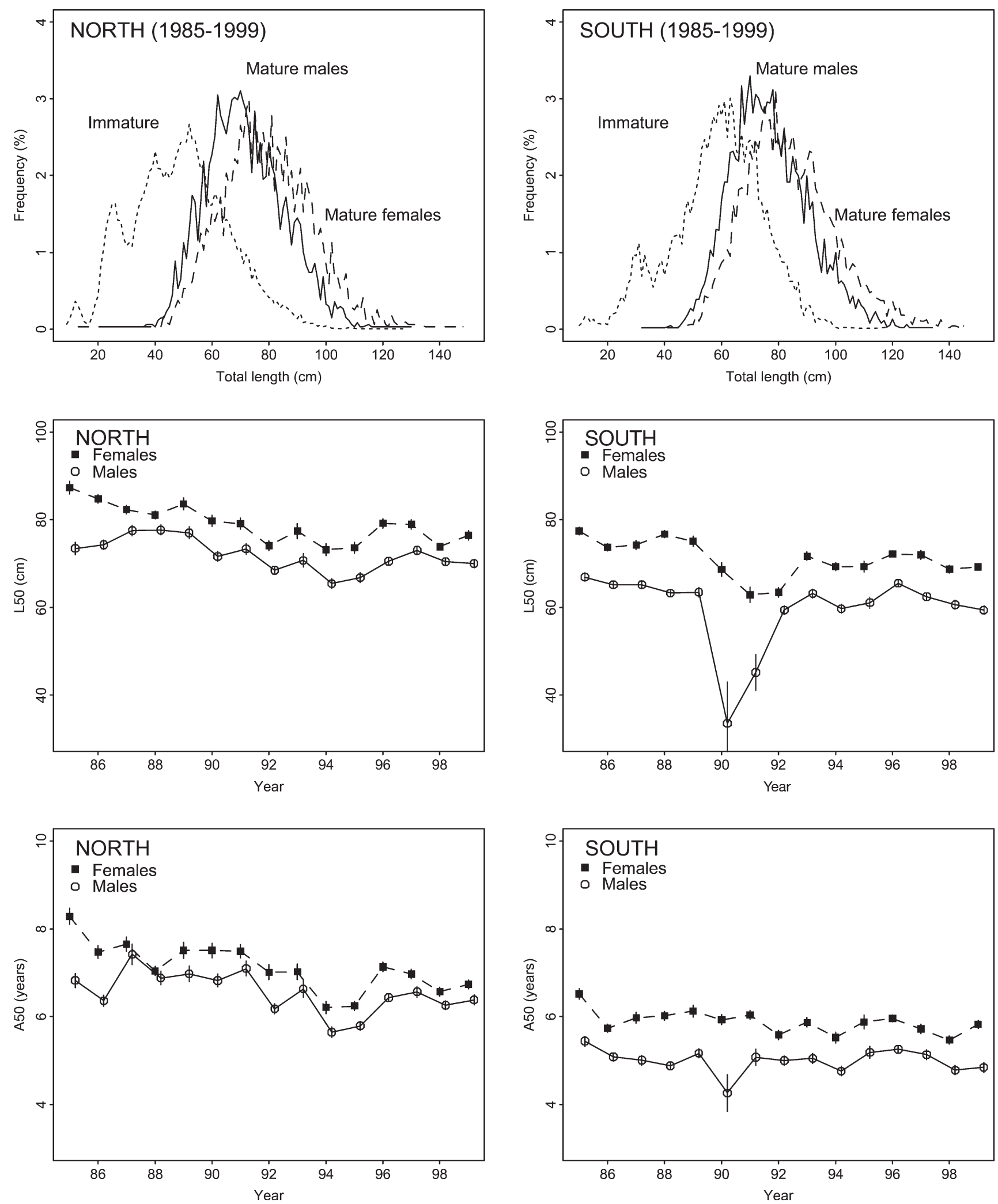

Fig. 2. Length frequency distributions for mature and immature cod (combined data 1985 to 1999$)$, and annual mean lengths $\left(L_{50}\right)$ and ages $\left(A_{50}\right)$ at $50 \%$ maturity $( \pm \mathrm{SE})$ for female and male cod in waters off the north and south coasts of Iceland 

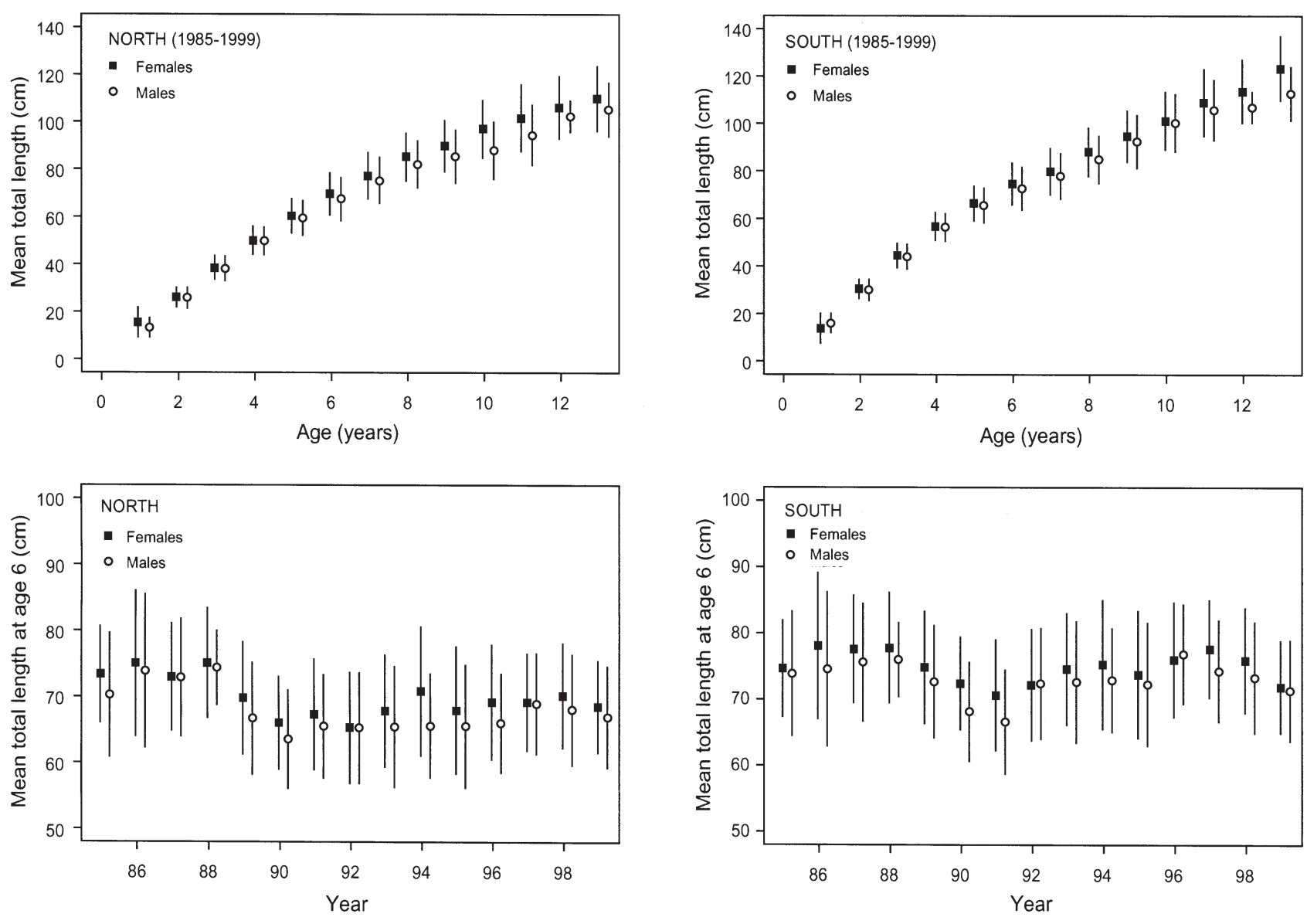

Fig. 3. Mean total length $(\mathrm{cm})$ at age (yr) for cod (combined data 1985 to 1999), and annual mean total length at age 6 ( \pm SD) for female and male cod in waters off the north and south coasts of Iceland

\section{Fecundity}

PF of Icelandic cod ranged from 0.23 to 31.7 million vitellogenic oocytes (Fig. 6). As expected, PF increased significantly with female length (Table $4 ; \mathrm{p}<0.001$ for each of the $6 \mathrm{yr}, 1999$ to 2000) and weight ( $p<0.001$ for each of the $6 \mathrm{yr}, 1999$ to 2000). The relationship between PF and TL for the entire data (1995 to 2000) was best described with a power equation ( $\mathrm{PF}=$ $0.0118 \times \mathrm{TL}^{4.372}, \mathrm{r}^{2}=0.81, \mathrm{n}=869$ ), while the relationship between PF and $W$ was linear $(\mathrm{PF}=-1491732+$ $\left.778 \times W(\mathrm{~g}), \mathrm{r}^{2}=0.85, \mathrm{n}=869\right)$. The relationship between PF and TL varied annually (ANCOVA, p < 0.001; Fig. 6). The greatest slopes were obtained in 1997 and 1998, and the smallest in 1996 and 1999 (Table 4). PF varied between years from $836 \times 10^{3}$ to $1726 \times 10^{3}$ for a standard fish of $70 \mathrm{~cm}$ length, $3294 \times$ $10^{3}$ to $4835 \times 10^{3}$ for $90 \mathrm{~cm}$ fish and $13850 \times 10^{3}$ to $15822 \times 10^{3}$ for a $120 \mathrm{~cm}$ fish (Table 4). The mean differences amounted to 106, 46 and $14 \%$, respectively, between years.
PF was influenced by female condition. Including either $W$ or $K$ in a model describing the relationship between PF and TL increased the amount of variation explained in all years $\left(\mathrm{r}^{2}=0.87,0.93,0.73,0.85,0.92\right.$, 0.89 in 1995 to 2000, respectively). However, addition of $K$ to a model describing the relationship between fecundity and $W$ did not improve the variation explained. In contrast, addition of $H$ to such a model had a significant effect in all years except 1996 and 1999 $(\mathrm{p}<0.01)$.

RF ranged from 51 to 1327 oocytes $\mathrm{g}^{-1}$ of whole body weight and was significantly related to TL in all years (Fig. 7, Table 5, $\mathrm{r}^{2}=0.14$ to 0.38). RF was also influenced by $K$ and and $H$ (Table 6). The influence of $K$ was significant in 1995 and 1997, while $H$ was significant in all years except 1996 and 1998 (p < 0.05). Generally, more variation was explained by $H$ than by $K$, and in some years $(1997,2000), H$ explained more variation in RF than TL (Table 6).

RF of a standard fish, $70 \mathrm{~cm}$ long, varied from 376 in 1997 to 573 eggs g $^{-1}$ in 1999 (Table 5). Similar trends of 

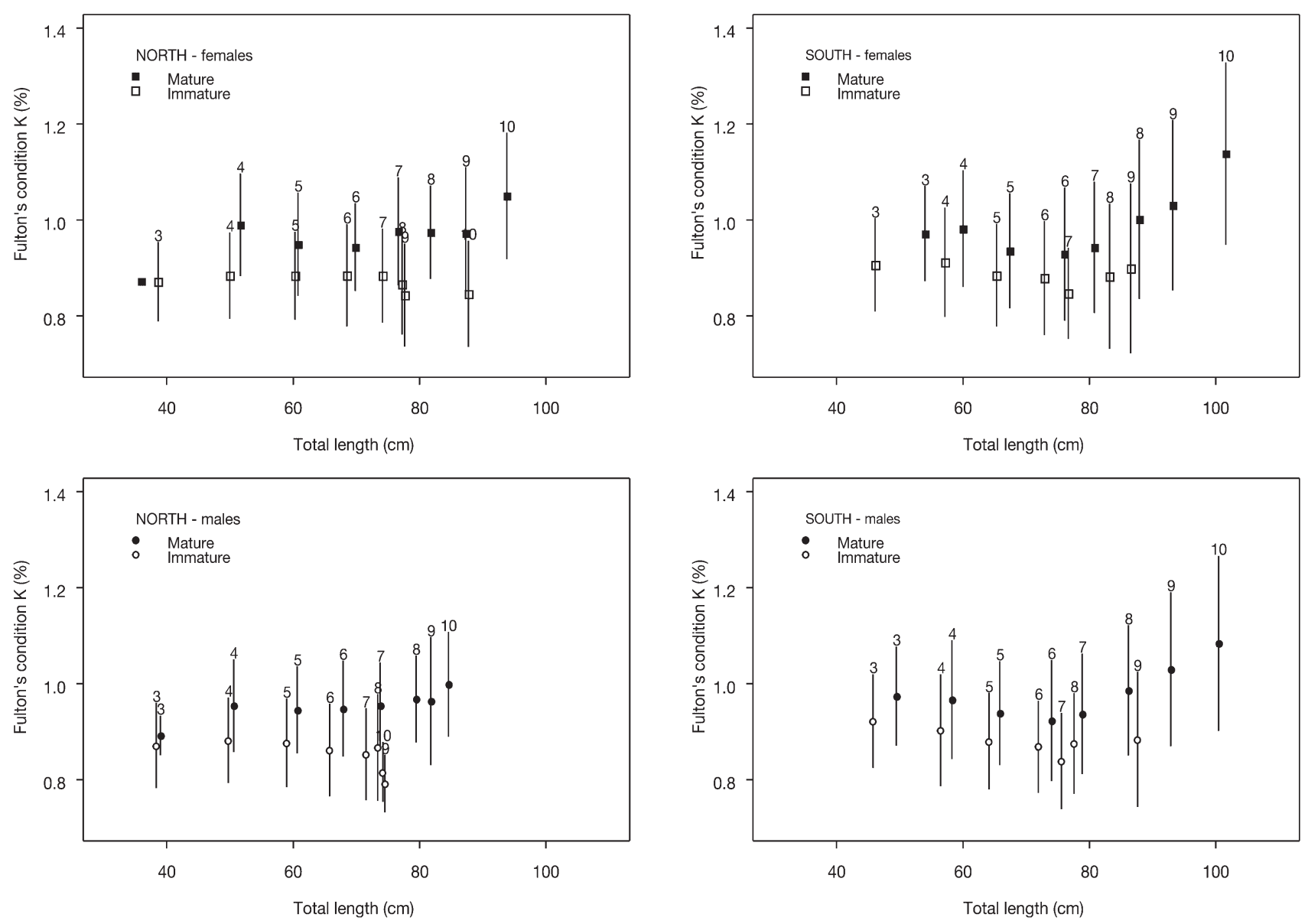

Fig. 4. Age-specific total length $(\mathrm{cm})$ and Fulton's condition index $(K)$ (mean $\pm \mathrm{SD})$ for mature and immature female and male cod in waters off the north and south coasts of Iceland (combined data 1985 to 1999)

lowest RF in 1997 and highest in 1999 were also observed for standard fish of 90 and $120 \mathrm{~cm}$ length (Table 5).

Batch fecundity (BF) ranged from 0.014 to 2.325 million hydrated oocytes present in the ovary at any given time during the spawning season (Fig. 8). Batch size appeared to be positively related to female total length $\left(\mathrm{r}^{2}=0.234, \mathrm{p}<0.001\right.$; Fig. 8), where the smallest females $(50$ to $80 \mathrm{~cm}$ ) did not produce batches greater than 0.5 million eggs and only females $>100 \mathrm{~cm}$ produced batches greater than 1.0 million eggs. However, for each female size class, batch size oscillated from close to 0 (presumably immediately after spawning) to a larger number (presumably when the size of the batch had been established). Batch size was also influenced by somatic condition, where an increased proportion of the variation was explained by including $K$ in the analysis $(\mathrm{BF}=-1116501+11811 \times L+380166 \times$ $\left.K ; \mathrm{r}^{2}=0.256, \mathrm{p}<0.0001\right)$. In contrast, the addition of $H$ did not have a significant effect on batch size $(\mathrm{p}>$ 0.80), nor did SPS ( $p>0.88$; Fig. 8).

\section{Eggs and larvae}

ED was significantly influenced by all variables including year, spawning stage and female total length ( $p<0.05$; Fig. 9, Table 7). However, within each spawning stage, significant results were only obtained for Stage II in $1994\left(\mathrm{ED}=1.27+0.0018 \times L, \mathrm{r}^{2}=0.31\right.$, $\mathrm{p}<0.05, \mathrm{n}=29)$ and $1996\left(\mathrm{ED}=1.24+0.0019 \times L, \mathrm{r}^{2}=\right.$ $0.23, \mathrm{p}=0.06, \mathrm{n}=15)$, and Stage III in $1996(\mathrm{ED}=$ $\left.1.28+0.0011 \times L, \mathrm{r}^{2}=0.14, \mathrm{p}<0.05, \mathrm{n}=35\right)$. Consistent with other reports (e.g. Solemdal et al. 1993), the regression relationships between ED and female $L$ in 1994 and 1996 for combined SPS II and III were also significant (Table 8). Analysis of the data for females in SPS II and III in 1994 and 1996, revealed that the slopes of the 2 fitted lines were not significantly different (ANCOVA, p > 0.711). However, the intercepts were significantly different (ANCOVA, $\mathrm{p}<0.001$ ). Including $K$ in the models had little influence on the amount of variation explained $\left(\mathrm{r}^{2}=0.243\right.$ [1994]; $\mathrm{r}^{2}=0.282$ [1996]) and the effects of $K$ were not significant at $\alpha=0.05$ 
Table 3. GLM results (null and residual deviance, pseudo- $\mathrm{R}^{2}$ ) and coefficients of maturity ogives incorporating the effects of length (TL), age $(A)$ and condition $(K)$ that were used to estimate proportion mature $(\mathrm{M})$ of female and male cod in waters off the north and south coasts of Iceland (combined data 1985-1999). $\mathrm{M}=1 / 1+\mathrm{e}^{-(-a+b \times X+c \times K)}$, where $X=\mathrm{TL}$ or $A$. Dev $=$ residual deviance (analogous to sums of squares)

\begin{tabular}{|c|c|c|c|c|c|c|c|c|c|}
\hline Sex & Region & a & $\begin{array}{c}\text { efficier } \\
b\end{array}$ & C & $\begin{array}{l}\text { Null } \\
\text { dev }\end{array}$ & $\begin{array}{l}\text { Res } \\
\text { dev }\end{array}$ & $\mathrm{R}^{2}$ & $\begin{array}{c}\text { Dev } \\
\text { TL }\end{array}$ & $\begin{array}{c}\text { Dev } \\
K\end{array}$ \\
\hline Females & $\begin{array}{l}\text { North } \\
\text { South } \\
\text { Total }\end{array}$ & $\begin{array}{r}-14.296 \\
-9.525 \\
-12.056\end{array}$ & $\begin{array}{l}0.104 \\
0.108 \\
0.112\end{array}$ & $\begin{array}{l}6.845 \\
2.110 \\
4.227\end{array}$ & $\begin{array}{r}8252.9 \\
6330.7 \\
16168.4\end{array}$ & $\begin{array}{l}5104.4 \\
4326.1 \\
9705.4\end{array}$ & $\begin{array}{l}0.38 \\
0.32 \\
0.40\end{array}$ & $\begin{array}{l}2737.7 \\
1962.3 \\
6129.0\end{array}$ & $\begin{array}{r}410.7 \\
42.3 \\
334.0\end{array}$ \\
\hline Males & $\begin{array}{l}\text { North } \\
\text { South } \\
\text { Total }\end{array}$ & $\begin{array}{r}-15.082 \\
-9.910 \\
-13.070\end{array}$ & $\begin{array}{l}0.109 \\
0.106 \\
0.117\end{array}$ & $\begin{array}{l}8.164 \\
3.769 \\
5.864\end{array}$ & $\begin{array}{r}8889.5 \\
6543.0 \\
17840.5\end{array}$ & $\begin{array}{r}5569.2 \\
4642.6 \\
10668.0\end{array}$ & $\begin{array}{l}0.37 \\
0.29 \\
0.40\end{array}$ & $\begin{array}{l}2740.1 \\
1779.5 \\
6554.8\end{array}$ & $\begin{array}{l}580.2 \\
120.8 \\
617.6\end{array}$ \\
\hline Both & $\begin{array}{l}\text { North } \\
\text { South } \\
\text { Total }\end{array}$ & $\begin{array}{r}-14.317 \\
-9.279 \\
-12.170\end{array}$ & $\begin{array}{l}0.103 \\
0.101 \\
0.110\end{array}$ & $\begin{array}{l}7.373 \\
2.913 \\
4.942\end{array}$ & $\begin{array}{l}17185.6 \\
13033.1 \\
34211.1\end{array}$ & $\begin{array}{r}10896.7 \\
9315.4 \\
20975.8\end{array}$ & $\begin{array}{l}0.37 \\
0.29 \\
0.39\end{array}$ & $\begin{array}{r}5322.7 \\
3558.4 \\
12314.5\end{array}$ & $\begin{array}{l}966.2 \\
159.3 \\
920.8\end{array}$ \\
\hline Sex & Region & $a$ & $\begin{array}{l}\text { efficier } \\
b\end{array}$ & C & $\begin{array}{l}\text { Null } \\
\text { dev }\end{array}$ & $\begin{array}{l}\text { Res } \\
\text { dev }\end{array}$ & $\mathrm{R}^{2}$ & $\begin{array}{c}\text { Dev } \\
\text { A }\end{array}$ & $\begin{array}{c}\text { Dev } \\
K\end{array}$ \\
\hline Females & $\begin{array}{l}\text { North } \\
\text { South } \\
\text { Total }\end{array}$ & $\begin{array}{l}-14.135 \\
-10.704 \\
-12.454\end{array}$ & $\begin{array}{l}1.061 \\
1.187 \\
1.149\end{array}$ & $\begin{array}{l}7.528 \\
4.263 \\
5.684\end{array}$ & $\begin{array}{r}7021.3 \\
4949.9 \\
13163.6\end{array}$ & $\begin{array}{l}4206.5 \\
3018.0 \\
7636.3\end{array}$ & $\begin{array}{l}0.40 \\
0.39 \\
0.42\end{array}$ & $\begin{array}{l}2424.5 \\
1799.1 \\
5043.1\end{array}$ & $\begin{array}{l}390.3 \\
132.8 \\
484.2\end{array}$ \\
\hline Males & $\begin{array}{l}\text { North } \\
\text { South } \\
\text { Total }\end{array}$ & $\begin{array}{l}-14.528 \\
-10.150 \\
-12.780\end{array}$ & $\begin{array}{l}1.023 \\
1.107 \\
1.109\end{array}$ & $\begin{array}{l}8.902 \\
5.053 \\
7.072\end{array}$ & $\begin{array}{r}7725.9 \\
5052.9 \\
14400.4\end{array}$ & $\begin{array}{l}4812.9 \\
3257.0 \\
8666.3\end{array}$ & $\begin{array}{l}0.38 \\
0.36 \\
0.40\end{array}$ & $\begin{array}{l}2318.8 \\
1625.2 \\
4968.7\end{array}$ & $\begin{array}{l}594.1 \\
170.8 \\
765.4\end{array}$ \\
\hline Both & $\begin{array}{l}\text { North } \\
\text { South } \\
\text { Total }\end{array}$ & $\begin{array}{l}-14.081 \\
-10.173 \\
-12.370\end{array}$ & $\begin{array}{l}1.016 \\
1.109 \\
1.100\end{array}$ & $\begin{array}{l}8.109 \\
4.623 \\
6.297\end{array}$ & $\begin{array}{l}14794.8 \\
10096.6 \\
27703.3\end{array}$ & $\begin{array}{r}9180.1 \\
6459.2 \\
16655.4\end{array}$ & $\begin{array}{l}0.38 \\
0.36 \\
0.40\end{array}$ & $\begin{array}{l}4655.7 \\
3331.9 \\
9826.7\end{array}$ & $\begin{array}{r}959.0 \\
305.5 \\
1221.3\end{array}$ \\
\hline
\end{tabular}

( $p=0.095$ [1994]; $p=0.079$ [1996]). A similar amount of variation was explained by including only female $W$ in the models $\left(E D=1.1510 \times W^{0.0248}, \mathrm{r}^{2}=0.246, \mathrm{p}<0.0001\right.$ [1994]; $\mathrm{ED}=1.0637 \times W^{0.0299}, \mathrm{r}^{2}=0.28, \mathrm{p}<0.0001$ [1996]). In addition to $L$, neither $H$ ( $\mathrm{p}>0.371$ [1994]; $\mathrm{p}>$ 0.785 [1996]) nor age $(p>0.865$ [1994]; $p>0.242$ [1996]) contributed significantly to the variation explained by the models.

Absolute density of eggs ( $\rho$ ) varied from 1.02256 to $1.02657 \mathrm{~g} \mathrm{~cm}^{-3}$. Egg density was significantly related to both female total length and egg diameter ( $p<$ 0.0001), indicating that larger females produced larger eggs of a greater density than did smaller females (Fig. 10). An analysis of the relative influence of female $L$, SPS and ED on egg density demonstrated that SPS did not have a significant effect on egg density $(p=0.587)$, while both total length and egg diameter contributed to the variation in egg density $\left(\mathrm{r}^{2}=0.46 ; \mathrm{p}<0.05\right)$. A model describing the influence of total body weight and ED on egg density explained only slightly more of the variation $\left(\mathrm{r}^{2}=\right.$ 0.49). Similarly, $K$, in addition to female $L$ and ED, did not have a significant effect on egg density ( $\mathrm{p}=$ 0.529). In contrast, $H$ had highly significant effects on egg density where 3 times more of the explained variation could be attributed to $H$ than to total length $\left(\rho=1.0208+0.0000153 \times L+0.00328 \times H S I, \mathrm{r}^{2}=0.51\right.$, $\mathrm{p}<0.0001)$

Variation in egg density $\left(\rho_{\mathrm{SD}}=\right.$ standard deviation of 20 egg density measurements within each female batch) was also significantly related to female TL and ED ( $p<0.001$; Fig. 10). More than $50 \%$ of the explained variation was attributed to $L$ (ln-transformed; $\mathrm{p}<0.039$ ) in comparison to the variation explained by the ED ( $p=0.073)$. Similarly, spawning stage had no effect on variation in egg density $(p=0.582)$. However, both $K$ and $H$ had a significant effect on the variation in egg density. Influence of $H$ was much greater than both $K$ and $L$, and in a model exploring the combined effects of $L$ and $H\left(\mathrm{r}^{2}=0.32\right)$, most of the variation in egg density was attributed to $H(p<0.001)$, while the effect of $L$ was not significant ( $p>0.45$ ).

In all years, both $L$ and $W$ of larvae increased with ED (Table 8, Fig. 11). Moreover, better model fits were observed between ED and larval dry weight than ED and $L$ (Fig. 11; Table 8). Larval length at $20 \mathrm{~d}$ was also shown to increase significantly with ED (Fig. 11; Table 8). However, only in 1994 was the SGR found to increase significantly with ED (SGR $=-7.649+8.744 \times$ $\left.\mathrm{SGR}, \mathrm{r}^{2}=0.18, \mathrm{p}<0.05\right)$. The range of SGR was similar among years (1994: 2.8 to $7.5 \%$; 1995: 4.4 to $9.1 \%$; 1996: 3.1 to 8.4 ). 



Fig. 5. Maturity ogives for female and male cod in waters off the north and south coasts of Iceland that were used to estimate the proportion of mature cod at each length for 3 condition $(K)$ classes $(K<0.8 ; K=0.8$ to $1.0 ; K>1.0)$ (combined data 1985 to 1999) 

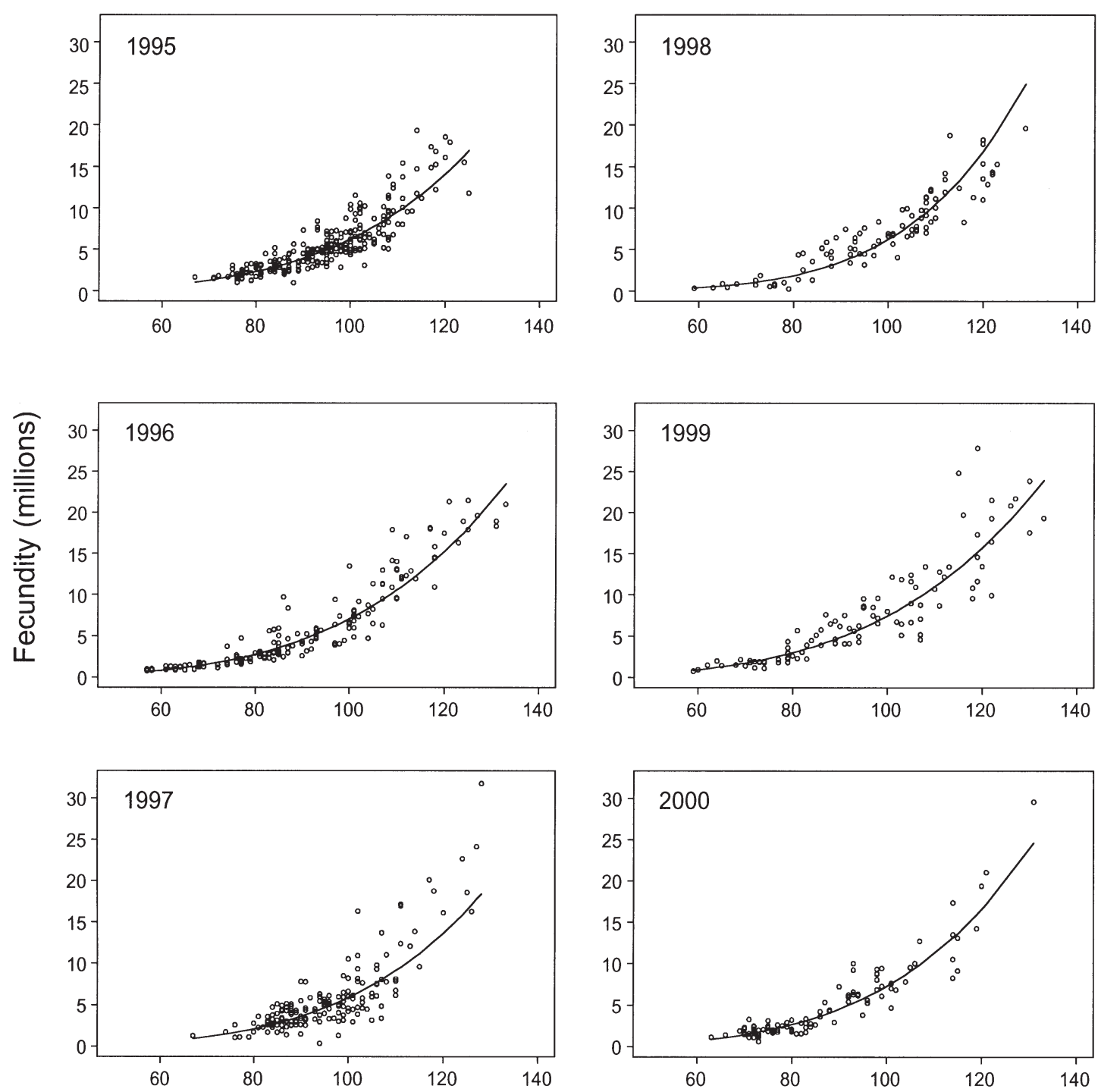

\section{Total length $(\mathrm{cm})$}

Fig. 6. Potential fecundity (PF) of cod in Icelandic waters, 1995 to 2000

\section{DISCUSSION}

Reproductive potentials of cod stocks throughout the north Atlantic are undoubtedly influenced by a multitude of factors interacting at both the individual and stock levels (Trippel et al. 1997a, Marshall et al. 1998, Marteinsdottir \& Thorarinsson 1998). We found reproductive potential in the Icelandic cod stock to be strongly influenced by the age, size and condition of individual spawning fish as well as the population demographics and life history characteristics of the spawning stock. Results from this study will provide fishery modelers with a set of fundamental relationships that will aid the estimation of reproductive potential in cod stocks throughout the north Atlantic, which, in turn, will support the re-examination of stock-recruitment relationships for these stocks. Based on these relationships, more accurate biological reference points can then be formulated for the development of more realistic fishery harvesting strategies (Marshall et al. 1998, Scott et al. 1999).

Age and size at sexual maturity are fundamental variables that influence the reproductive potential of a fish stock (Jørgensen 1990, Rijinsdorp et al. 1991, Trippel et al. 1997a). Often in fisheries stock assessments these variables are assumed to be constant over extensive spatial and temporal scales (Rijinsdorp et al. 1991, Marshall et al. 1999), with little regard for the plasticity 


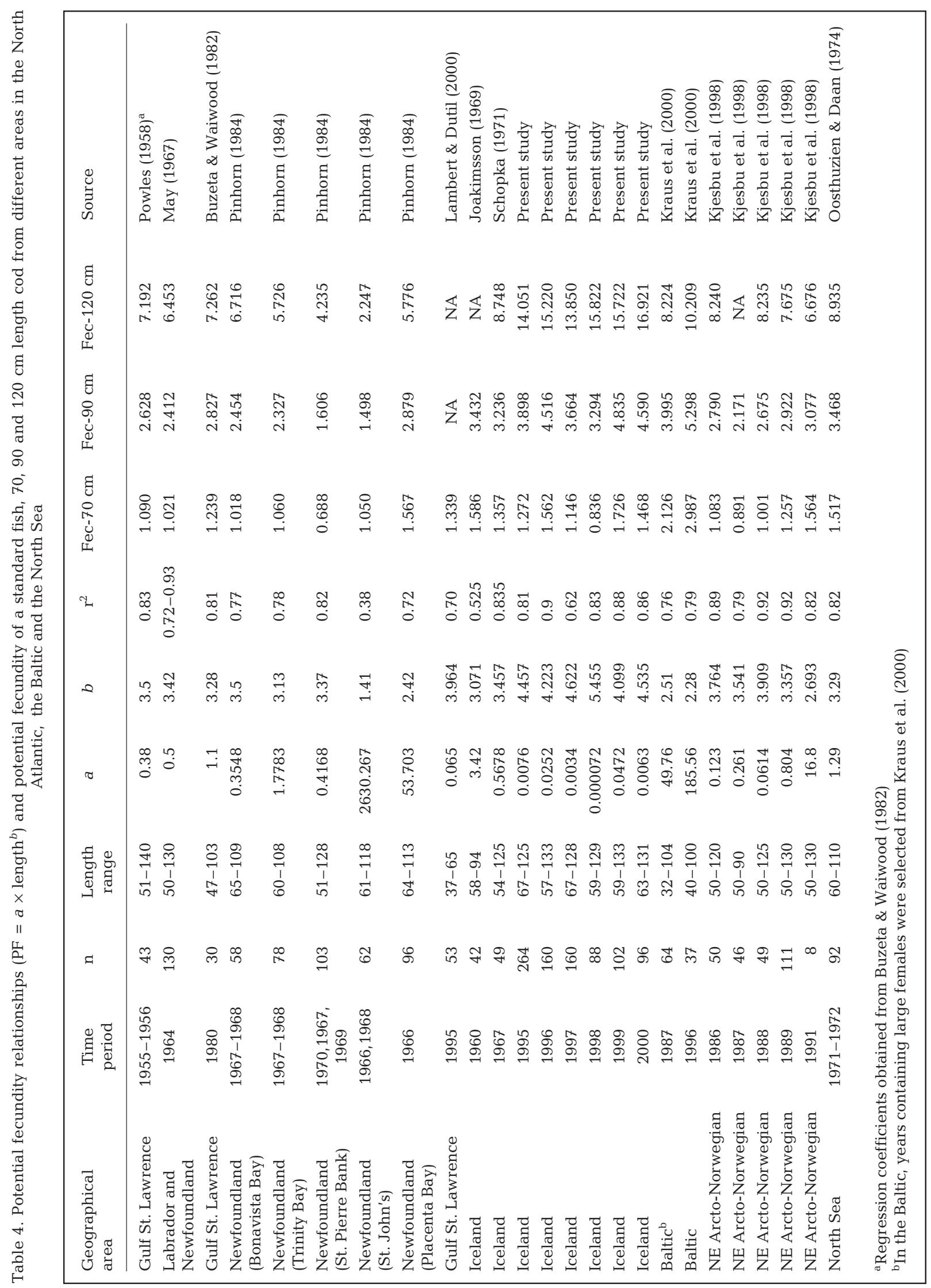



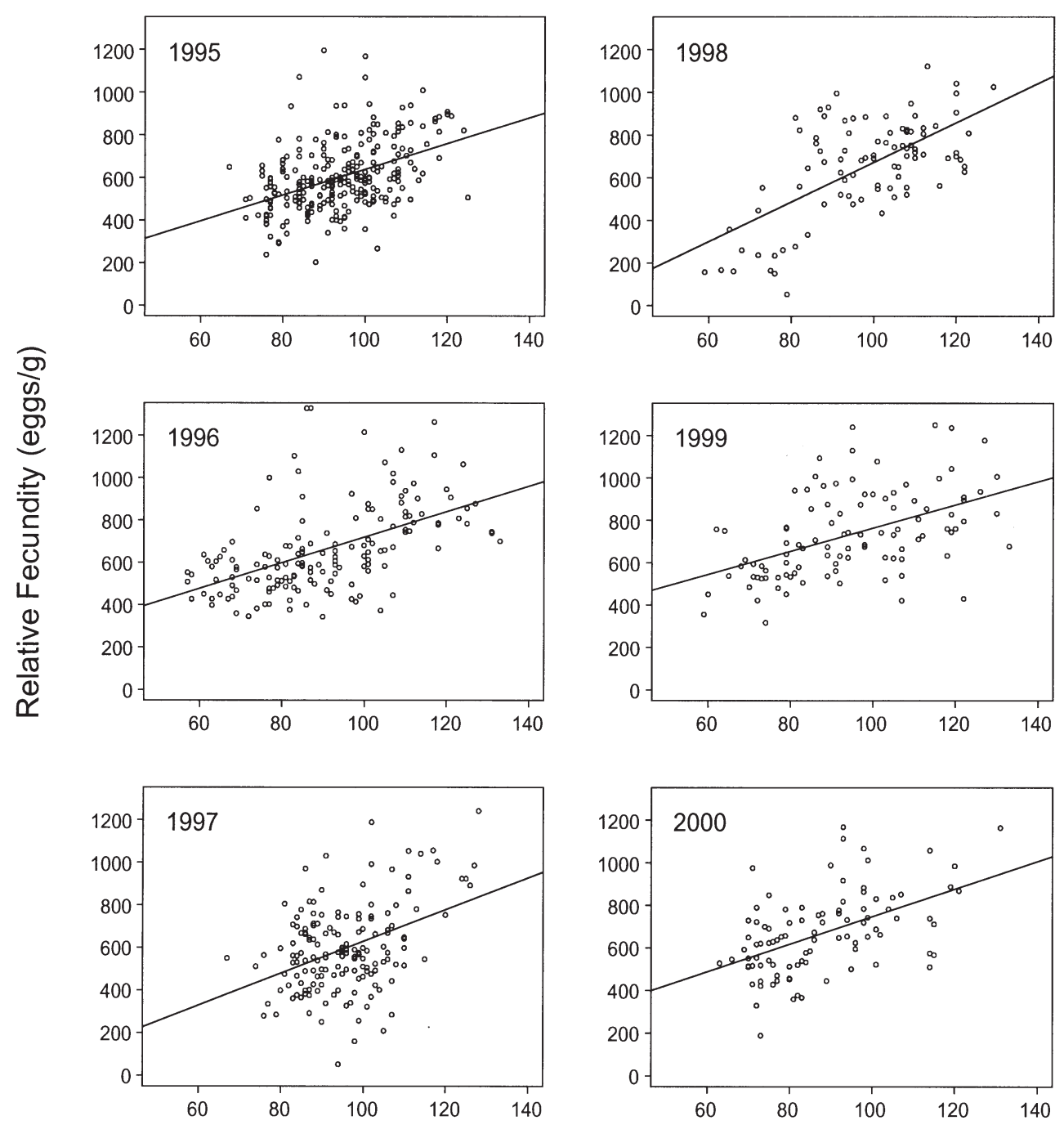

\section{Total length $(\mathrm{cm})$}

Fig. 7. Relative fecundity (RF) of cod in Icelandic waters, 1995 to 2000

in these flexible life history characteristics to fishing exploitation and environmental perturbations (Stearns \& Crandall 1984). Indeed, similar to other cod stocks throughout the north Atlantic (Holdway \& Beamish 1985, Godø \& Moksness 1987, Trippel et al. 1997b, Begg et al. 1999, Cardinale \& Modin 1999, O'Brien 1999), the Icelandic cod stock demonstrated significant sexual, spatial and temporal variation in age and size at maturity (Fig. 2) that were strongly affected by growth and condition (Fig. 5). Faster-growing cod in waters off the south coast of Iceland attained sexual maturity at a smaller size and younger age than slower- growing cod off the north coast. Moreover, the influence of condition on maturity was more apparent for cod in waters off the north coast, particularly for size at

Table 5. Regression equations for relative fecundity (RF: $\mathrm{g}^{-1}$ whole body weight) on female length $(L)$ in 1995 to 2000 . Estimated relative fecundity for a standard fish, 70 and $90 \mathrm{~cm}$ long

\begin{tabular}{|clccccc|}
\hline Year & Regression & $\mathrm{r}^{2}$ & $\mathrm{p}$ & $\mathrm{RF}-70$ & $\mathrm{RF}-90$ & $\mathrm{RF}-120$ \\
\hline 1995 & $\mathrm{RF}=91.2+4.8 \times \mathrm{L}$ & 0.2 & $<0.001$ & 427 & 523 & 667 \\
1996 & $\mathrm{RF}=184.7+4.6 \times \mathrm{L}$ & 0.23 & $<0.001$ & 507 & 599 & 737 \\
1997 & $\mathrm{RF}=-8.4+5.5 \times \mathrm{L}$ & 0.14 & $<0.001$ & 377 & 486 & 652 \\
1998 & $\mathrm{RF}=-200.2+8.3 \times \mathrm{L}$ & 0.38 & $<0.001$ & 381 & 547 & 796 \\
1999 & $\mathrm{RF}=258.6+4.5 \times \mathrm{L}$ & 0.19 & $<0.001$ & 574 & 664 & 799 \\
2000 & $\mathrm{RF}=168.6+5.1 \times \mathrm{L}$ & 0.21 & $<0.001$ & 525 & 628 & 781 \\
& & & & & & \\
\hline
\end{tabular}


Table 6. Analysis of the effects of length, somatic condition $(K)$ and liver condition $(H)$ on relative fecundity of cod (number of eggs $\mathrm{g}^{-1}$ total body weight). Results include the range of values for each source of variation in the model, coefficients (the intercepts listed in the top line for each year), marginal sums of squares (Type III in thousands), results of the $F$ statistics (rounded to a whole number), the probability levels and proportion of variation explained by the model

\begin{tabular}{|c|c|c|c|c|c|c|c|}
\hline Year & $\begin{array}{l}\text { Source of } \\
\text { variation }\end{array}$ & $\begin{array}{l}\text { Range of } \\
\text { values }\end{array}$ & Coefficients & $\begin{array}{l}\text { Sums of } \\
\text { squares }\end{array}$ & $F$ & $\mathrm{p}>F$ & $\mathrm{r}^{2}$ \\
\hline 1995 & $\begin{array}{c}\text { Total model } \\
\text { Length } \\
K \\
H\end{array}$ & $\begin{array}{r}67-125 \\
0.46-1.49 \\
2.7-15.8\end{array}$ & $\begin{array}{r}-96.15 \\
4.35 \\
115.87 \\
13.57\end{array}$ & $\begin{array}{r}1213 \\
479 \\
63 \\
266\end{array}$ & $\begin{array}{r}29 \\
35 \\
5 \\
20\end{array}$ & $\begin{array}{c}<0.0001 \\
<0.001 \\
0.031 \\
<0.001\end{array}$ & 0.26 \\
\hline 1996 & $\begin{array}{c}\text { Total model } \\
\text { Length } \\
K \\
H\end{array}$ & $\begin{array}{c}57-133 \\
0.73-1.59 \\
1.7-14.4\end{array}$ & $\begin{array}{r}127.45 \\
3.55 \\
84.79 \\
9.42\end{array}$ & $\begin{array}{r}4701 \\
299 \\
17 \\
73\end{array}$ & $\begin{array}{r}22 \\
13 \\
1 \\
3\end{array}$ & $\begin{array}{r}<0.001 \\
<0.001 \\
0.374 \\
0.071\end{array}$ & 0.26 \\
\hline 1997 & $\begin{array}{c}\text { Total model } \\
\text { Length } \\
K \\
H\end{array}$ & $\begin{array}{r}67-128 \\
0.73-1.59 \\
3.0-12.6\end{array}$ & $\begin{array}{r}-188.12 \\
2.86 \\
194.85 \\
27.64\end{array}$ & $\begin{array}{r}4183 \\
114 \\
141 \\
359\end{array}$ & $\begin{array}{r}21 \\
6 \\
7 \\
18\end{array}$ & $\begin{array}{r}<0.001 \\
0.016 \\
0.008 \\
<0.001\end{array}$ & 0.29 \\
\hline 1998 & $\begin{array}{c}\text { Total model } \\
\text { Length } \\
K \\
H\end{array}$ & $\begin{array}{r}59-129 \\
0.68-1.35 \\
2.1-13.5\end{array}$ & $\begin{array}{r}-391.80 \\
8.36 \\
73.26 \\
15.18\end{array}$ & $\begin{array}{r}3999 \\
820 \\
4 \\
67\end{array}$ & $\begin{array}{r}19 \\
29 \\
1 \\
3\end{array}$ & $\begin{array}{r}<0.001 \\
<0.001 \\
0.678 \\
0.125\end{array}$ & 0.41 \\
\hline 1999 & $\begin{array}{c}\text { Total model } \\
\text { Length } \\
K \\
H\end{array}$ & $\begin{array}{c}59-133 \\
0.75-1.46 \\
2.7-18.9\end{array}$ & $\begin{array}{r}67.51 \\
2.69 \\
233.26 \\
15.82\end{array}$ & $\begin{array}{r}3456 \\
156 \\
100 \\
128\end{array}$ & $\begin{array}{r}12 \\
6 \\
4 \\
5\end{array}$ & $\begin{array}{r}<0.001 \\
0.016 \\
0.053 \\
0.028\end{array}$ & 0.27 \\
\hline 2000 & $\begin{array}{c}\text { Total model } \\
\text { Length } \\
K \\
H\end{array}$ & $\begin{array}{r}63-131 \\
0.72-1.57 \\
1.8-13.4\end{array}$ & $\begin{array}{r}-41.51 \\
4.47 \\
60.82 \\
27.60\end{array}$ & $\begin{array}{r}2734 \\
179 \\
4 \\
288\end{array}$ & $\begin{array}{r}15 \\
9 \\
1 \\
14\end{array}$ & $\begin{array}{r}<0.001 \\
0.004 \\
0.643 \\
<0.001\end{array}$ & 0.33 \\
\hline
\end{tabular}

Table 7. Mean (mm) and standard deviation of egg diameters in 1994 and 1996 grouped by spawning stages and female size groups

\begin{tabular}{|c|c|c|c|c|c|c|c|c|c|c|c|c|}
\hline \multirow{2}{*}{$\begin{array}{l}\text { Female size } \\
\text { groups }\end{array}$} & \multicolumn{3}{|c|}{ SPS-I } & \multicolumn{3}{|c|}{ SPS-II } & \multicolumn{3}{|c|}{ SPS-III } & \multicolumn{3}{|c|}{ SPS-IV } \\
\hline & $\mathrm{n}$ & Mean & $\mathrm{SD}$ & $\mathrm{n}$ & Mean & SD & $\mathrm{n}$ & Mean & $\mathrm{SD}$ & $\mathrm{n}$ & Mean & $\mathrm{SD}$ \\
\hline \multicolumn{13}{|l|}{1994} \\
\hline$>100 \mathrm{~cm}$ & 1 & - & - & 19 & 1.48 & 0.06 & 12 & 1.46 & 0.06 & 8 & 1.35 & 0.04 \\
\hline $75-100 \mathrm{~cm}$ & - & - & - & 7 & 1.45 & 0.08 & 7 & 1.42 & 0.07 & 1 & - & - \\
\hline$<75 \mathrm{~cm}$ & - & - & - & 4 & 1.39 & 0.03 & 14 & 1.41 & 0.05 & 6 & 1.31 & 0.04 \\
\hline \multicolumn{13}{|l|}{1996} \\
\hline$>100 \mathrm{~cm}$ & 4 & 1.42 & 0.06 & 9 & 1.44 & 0.07 & 9 & 1.41 & 0.05 & 1 & - & - \\
\hline $75-100 \mathrm{~cm}$ & - & - & - & 5 & 1.43 & 0.04 & 21 & 1.36 & 0.04 & 6 & 1.33 & 0.06 \\
\hline$<75 \mathrm{~cm}$ & - & - & - & 1 & - & - & 5 & 1.36 & 0.04 & 6 & 1.33 & 0.06 \\
\hline
\end{tabular}

maturity, where distinct differences were detected between cod of variable condition. The influence of condition may be more significant for cod in the north, where waters are cooler and more variable, and hence less conducive to growth and survival than waters in the south, which tend to be on average at least $4^{\circ} \mathrm{C}$ warmer (Malmberg \& Kristmannsson 1992, Begg \& Marteinsdottir 2000). The more variable environment in the north may exacerbate life history differences between fish in good and poor condition, as has been found in other studies where poor condition was correlated with slow growth (Lambert \& Dutil 1997a,b). Alternatively, the disparity in age and size at maturity between cod in waters off the north and south coasts may be due to variable fishing pressure, where greater exploitation of spawning fish exists on the main spawning grounds off the south coast (Begg \& Marteinsdottir 2002a,b). 

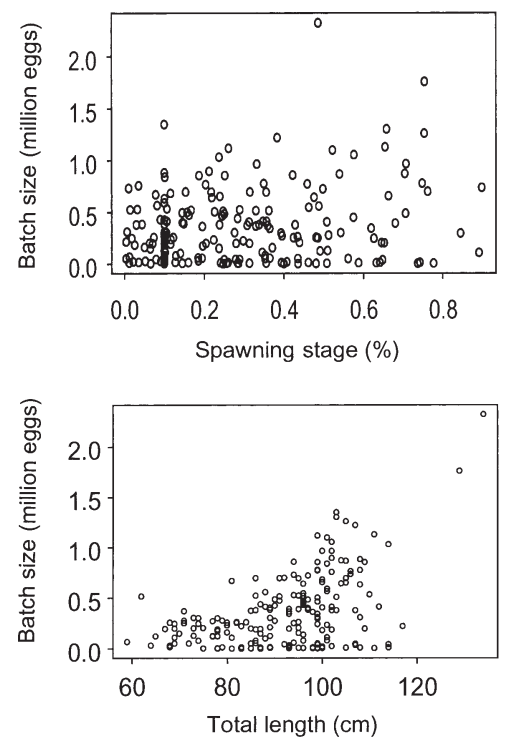

Fig. 8. Batch size vs female total length $(\mathrm{cm})$ and spawning stage




Fig. 9. Linear relationships between female total length $(\mathrm{cm})$ and egg diameter (ED), 1994 to 1996. Shown are fitted regression lines for female cod in Spawning Stages II and III in 1994 (solid line) and 1996 (dashed line). Regression equations are listed in Table 8
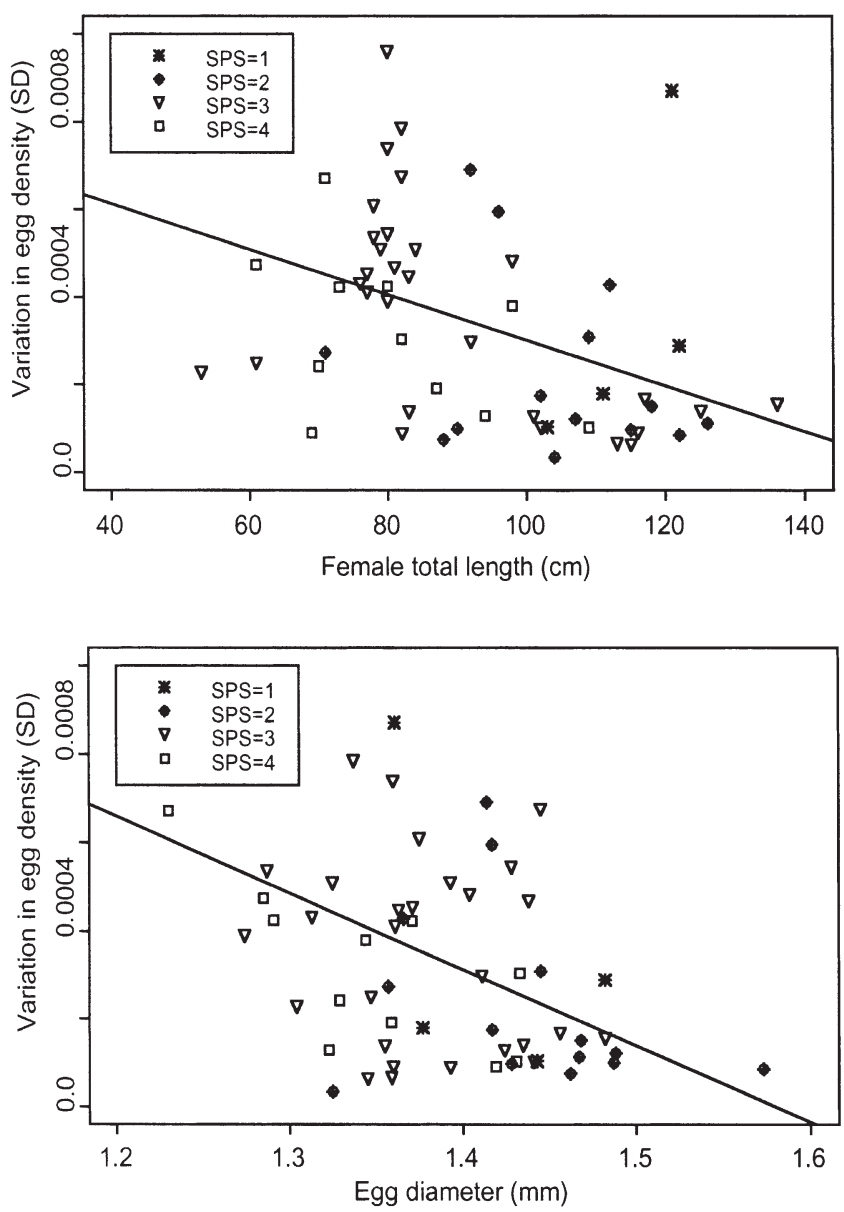

Fig. 10. Linear relationships between female total length, egg diameters (ED), egg density ( $\rho$ ) and the variation in egg density in 1996 


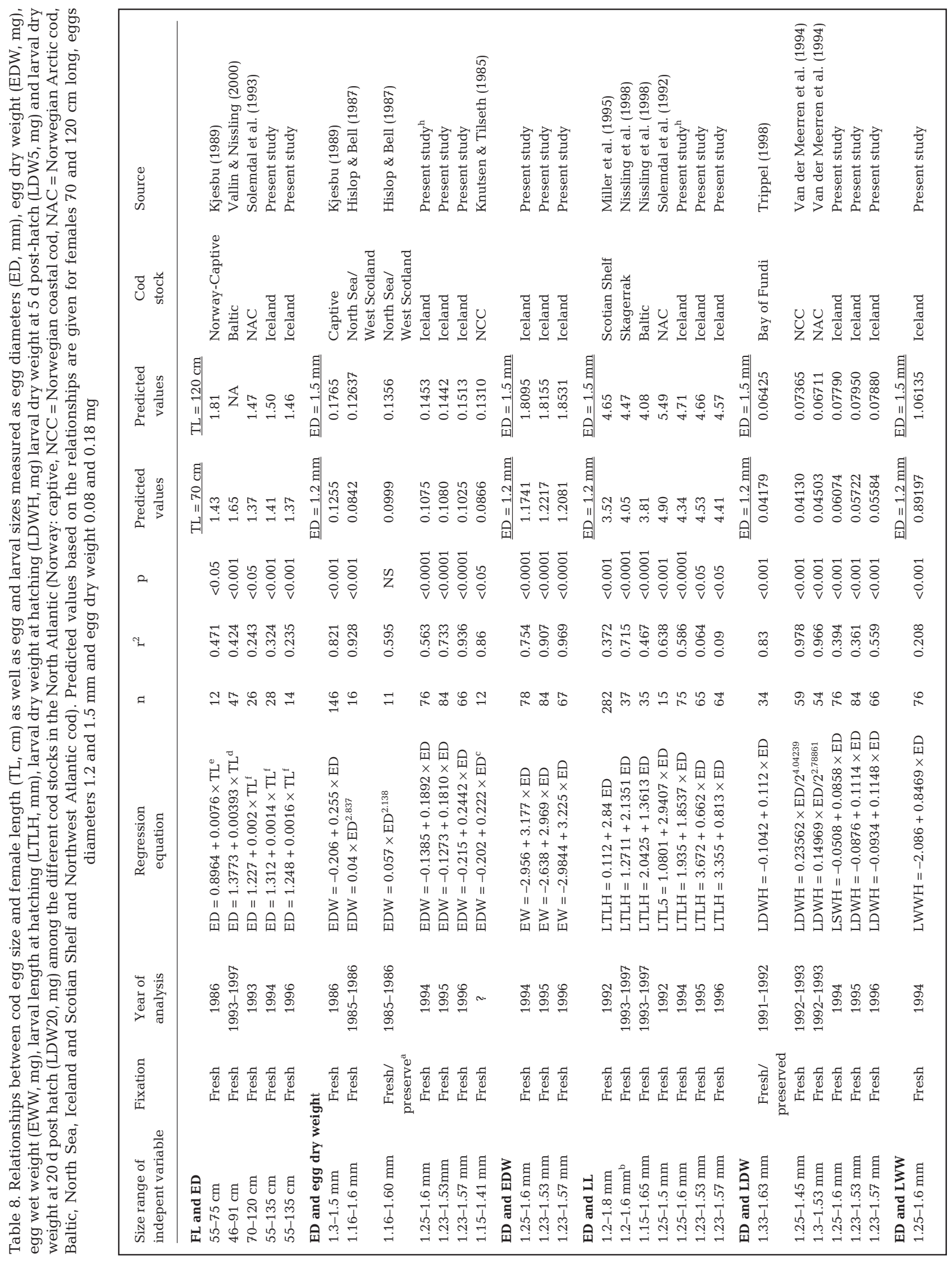




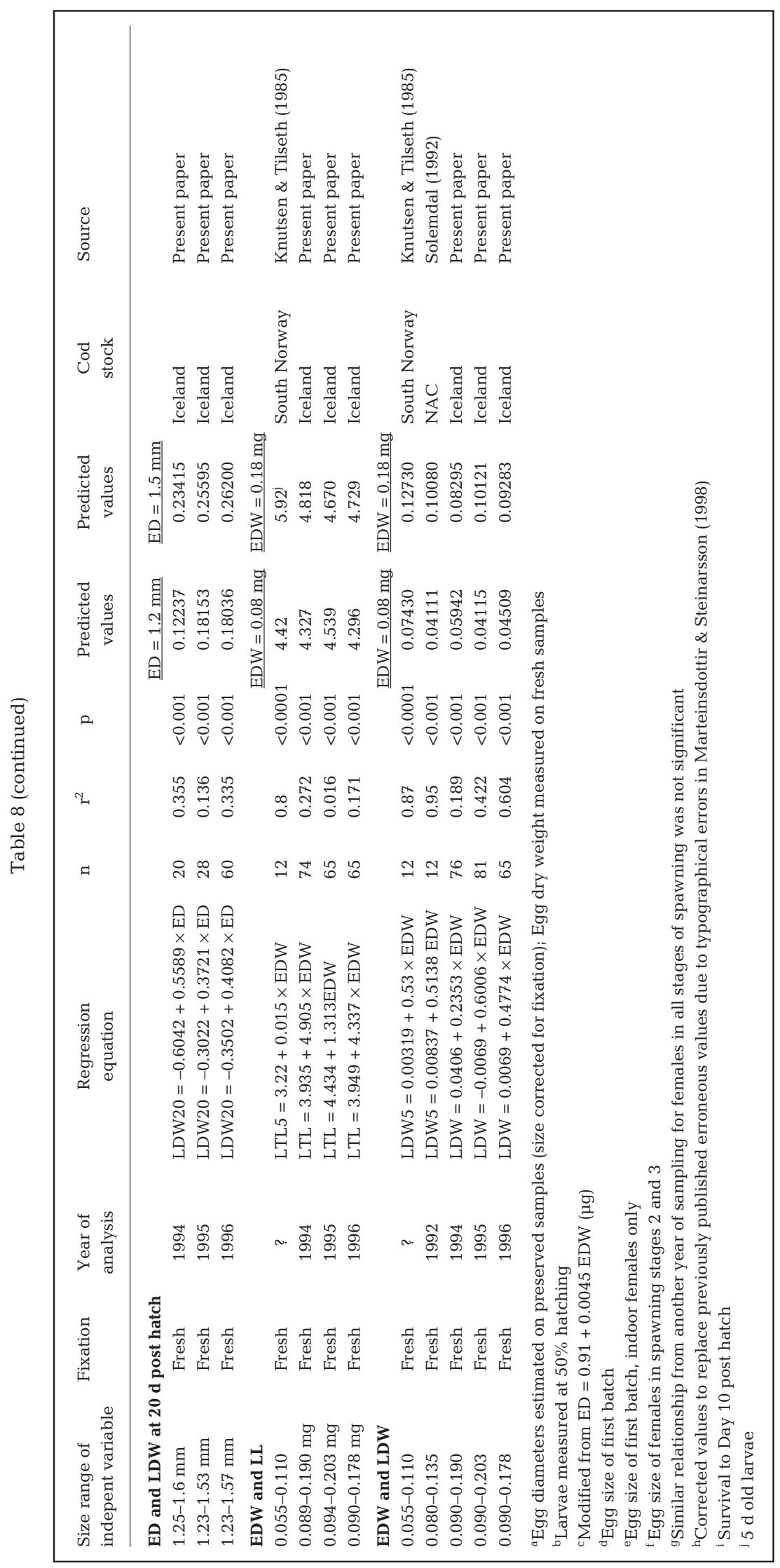





Fig. 11. Linear relationship between egg diameters (ED) and larval length at hatching and at age $20 \mathrm{~d}$ in 1994, 1995 and 1996

During the past few decades cod stocks across the entire north Atlantic have experienced declines in size and age at maturity, associated with severe declines in abundance and selective removal of older and larger spawners as a result of increased exploitation (Holdway \& Beamish 1985, Jørgensen 1990, Rijinsdorp et al. 1991, Trippel et al. 1997b, Begg et al. 1999). Similarly, the Icelandic cod stock has experienced changes in age and size composition, as well as abundance (Marteinsdottir \& Thorarinsson 1998), resulting in significant reductions in age and size at maturity of $2.8 \mathrm{yr}$ and $24 \mathrm{~cm}$ during the survey period (excluding 1990 to 1991; Fig. 2). Notably, reductions in sexual maturity have been linked to compensatory responses in total egg production, where Trippel et al. (1997a) estimated a $16 \%$ increase in egg production when age at maturity was reduced by 1 yr compared to what it would have been with no reduction. However, more significant is that increased exploitation rates have resulted in cod stocks being comprised largely of recruit spawners due to the disproportionate loss of older and larger repeat spawners (Trippel et al. 1997b, Murawski et al. 1999), adversely affecting both the quantity and quality of total egg production (Marshall et al. 1998, Scott et al. 1999). In the Icelandic cod stock, periods of narrow age distributions have become more frequent and fewer fish now survive beyond 7 or 8 yr of age (Marteinsdottir \& Thorarinsson 1998). Consequently, accounting for variability in rates of sexual maturity, including the rarely addressed influence of condition, is important in modelling reproductive potential, as shifts in maturity can significantly affect the composition of a spawning stock and its subsequent reproductive outputs. Furthermore, accurate differentiation of recruit and repeat spawners is an area that requires greater research, particularly owing to the assumed contribution of spawning experience to reproductive potential.

While fecundity does not give information on offspring viability, it does provide the starting number of potential offspring that can be produced and is therefore one of the essential components for estimating an individual's reproductive potential. As in other studies on cod (Table 4 in Kjesbu et al. 1998), we found that fecundity was strongly influenced by size and condition of the female. The influence of condition and especially the liver index on potential and relative fecundity has, however, not been confirmed so clearly before (Oosthuzien \& Daan 1974, Kjesbu et al. 1998). The proportionally stronger influence of liver condition on relative fecundity compared to length in the present study underscores the need for thorough monitoring of spawner condition levels, as well as all factors that influence condition and growth of indviduals within a stock. Similarly, accumulating evidence has demonstrated that substantial differences exist in sizespecific RF (39 to $73 \%$ increase in RF between standard fish of 70 and $120 \mathrm{~cm}$ length in the present study and 32 to $86 \%$ increase for 50 to $120 \mathrm{~cm}$ North Arctic cod in Kjesbu et al. [1998]). This result alone undermines the simplistic use of spawning stock biomass to estimate reproductive potential.

The potential utility of realistic spawner-fecundity relationships to more accurately model reproductive potential also emphasizes the need for more information on temporal and spatial variation in these relationships. In the present study, coefficients of fecundity-length relationships varied significantly from one year to another. Temporal variations in length-specific fecundity relationships may have many causes, including variable growth rates and condition levels among different size classes, changes in environmental factors that explain residual variation in fecundity (Buzeta \& Waiwood 1982, Kjesbu et al. 1998, Lambert \& Dutil 2000) and biased sampling resulting in unequal representation of different stock units of genetically diverse origin.

Comparisons of potential fecundity revealed a considerable spatial variation among different stocks of cod in the north Atlantic. Fecundity of the Icelandic cod appeared to be higher than fecundity of ArctoNorwegian cod and the NW Atlantic cod. Fecundity for large Icelandic cod was also higher than that for Baltic 
and North Sea cod of a similar size. The slopes for the Icelandic relationships obtained in the present study (4th to 5th power) were higher than any of the other stocks (closer to 2nd to 3rd power; Table 4). Furthermore, the slopes of the fecundity-length relationships were higher for cod in the present study than for cod of a similar size sampled in 1967 (Schopka 1971, Table 4; fecundity estimated gravimetrically as in the present study). The relatively low fecundity of large female cod in 1967 may reflect the unfavorable environmental conditions in the Icelandic waters during 1965 to 1971 , often referred to as the 'ice-years'. This period (the beginning of the 'Great Salinity Anomaly of 1970') was characterized by an extension of sea ice, exceptionally low sea temperatures north and east of the country, and low populations levels of Calanus finmarchius (Astthorsson et al. 1983, Jakobsson 1992, Astthorsson \& Gislason 1995). These environmental conditions were shown to influence the herring Clupea harengus stocks (Jakobsson 1992) and are likely to have also influenced the capelin Mallotus villosus stock, the main diet of cod in Icelandic waters.

Such pronounced spatial and temporal variation in fecundity emphasizes that caution is needed when attempting to generalize from 1 year or 1 stock to another. A difference in potential fecundity of 1 to 2 million eggs female ${ }^{-1}$ will lead to very large differences at the population level. It also highlights the need for annual monitoring of fecundity from all the main spawning components of the stocks.

An important question concerns the influence of female age, size and condition on offspring viability and survival. In addition to our study, a number of others have demonstrated significant relationships between maternal effects and offspring size (Kjesbu 1989, Solemdal et al. 1993, Trippel 1998, Chambers \& Waiwood 1996, Marteinsdottir \& Steinarsson 1998, Vallin \& Nissling 2000). However, only 2 have demonstrated a direct connection between egg size and larval survival (Marteinsdottir \& Steinarsson 1998, Nissling et al. 1998). Several studies have, however, shown that the smaller eggs of recruit spawners exhibit lower fertilization rates and greater mortality during incubation (Solemdal 1997, Trippel 1998, Trippel et al. 1999) and that initial larval size, condition and growth are related to egg size (Knutsen \& Tilseth 1985, Miller et al. 1995, Pepin et al. 1997, Marteinsdottir \& Steinarsson 1998, Nissling et al. 2000).

The pattern and magnitude of variation in female size-egg size relationships at the inter- and intra-stock level remains a perplexing problem. The measurements for Icelandic cod from 1994 and 1996 showed that the slopes of the relationships were similar but the intercepts were significantly different, due to a generally greater egg size in 1994. Similarly, the slopes of the relationships of North Arctic cod (NAC; Solemdal et al. 1993) and Icelandic cod appeared to be remarkably similar (Table 8), while the intercept of the NAC was lower than the intercepts for the Icelandic relationships. In contrast, the female-egg size relationship for Baltic cod has a much steeper slope due to production of much larger eggs (1.45 to $1.8 \mathrm{~mm}$ ), especially by the larger females (Vallin \& Nissling 2000).

Egg diameters, egg dry weights and larval sizes were in all cases significantly correlated (Table 8). However, comparisons of weights and lengths between individual studies are difficult, because different techniques are used for size estimation of eggs and larvae. Regardless, considerable variation appears to exist in these relationships both at the inter- and intrastock level. Therefore, comparative studies using standardized techniques to estimate size of eggs and larvae, as well as growth and viability, are needed. Such studies would undoubtedly reveal stock-specific differences that may reflect adaptations to local conditions.

The present study also shows that there is considerable variation in egg density, both with respect to female and egg sizes and within female egg batches. In general, density of eggs increased with female size, liver condition and egg size. This is in contrast to other studies on cod by Kjesbu et al. (1992), Nissling et al. (1994) and Vallin \& Nissling (2000), which have shown a significant negative correlation between egg size and specific gravity. It should be noted, however, that the observations made by Kjesbu et al. (1992) represent a seasonal decline in density, as well as, being based on relatively few and much smaller females $(26$ to $74 \mathrm{~cm}$ ) than those examined here (55 to $135 \mathrm{~cm}$ ). Furthermore, density of eggs produced by second-time spawners were initially greater than density of eggs produced by the same females the year before (Kjesbu et al. 1992), indicating that the relationship between egg density and size among the Norwegian coastal cod may actually be similar to the one for Icelandic cod.

Egg density and vertical distribution of eggs and larvae are likely to reflect adaptation to local environmental condition and transport scenarios. For example, egg density plays a major role in determining survival of eggs and larvae in the Baltic, where greater buoyancy is needed to keep the eggs above the low oxygen and high salinity layer (Vallin \& Nissling 2000). In Iceland, on the main spawning grounds along the SW coast, large cod are known to spawn close to the shore (Marteinsdottir et al. 2000a) and their eggs are likely to be distributed relatively deeper in the water column (at salinity of neutral buoyancy 32 to $34.5 \mathrm{psu}$ ), but over a narrower range of depths than eggs of smaller fish that spawn in deeper water on the Selvogsbanki and along the continental edge. This distribution may well represent an adaptation to differential current and transport 
mechanisms. Drift of eggs in the area close to shore is thought to be governed by the westward-flowing coastal current induced by the freshwater runoff of the large glacial rivers on the south shore of Iceland (Olafsson 1985, Thordardottir 1986, Marteinsdottir et al. 2000b, Begg \& Marteinsdottir 2002c). The neutral buoyancy of the larger eggs would position them within the lower range of the upper density layer. Much less is known about the currents and transport mechanism from the regions further away from the shore. The smaller cod that characteristically spawn in this area (Marteinsdottir et al. 2000a) produce smaller eggs on average. The neutral buoyancy of these eggs (29 to $32 \mathrm{psu}$ ) will position them close to the surface or well within the upper stratification layer.

\section{Conclusion}

Our results show that not only size, but also condition of spawners may have significant effects on reproductive potential. Condition, measured both as somatic condition and relative liver weight, influence the time of maturation, as well as quality and magnitude of egg production. Fish respond to fisheries and environmental perturbations in complex ways. Consequently, we can no longer ignore the plasticity of life history traits in assessment and management. The effects of female size and condition on reproductive potential underscore the importance of maintaining wide age distributions and relatively high numbers of spawners in the older year classes. Furthermore, implications of potential loss of genetic components of larger, older spawners has not been considered at all. In Icelandic waters, distinct differences in growth and condition are observed between adjacent spawning areas within the main spawning region (Marteinsdottir et al. 2000a), indicating that the population structure of cod may be a complex mosaic of groups that grow at different rates and vary with respect to relative contribution to recruitment of the total management unit.

It would be highly remiss of scientists working under the guise of the precautionary approach to overlook these complex yet tractable features.

Acknowledgements. Our thanks to Kristin Hardardottir, Gróa Petursdottir, Adalbjörg Jónsdóttir, Karen Bolles, Sigrún Jóhannsdóttir and Björn Gunnarsson for collection and processing of the reproductive samples; and the survey leaders, Olafur K. Palsson, Sigfús A. Schopka, and Sólmundur Einarsson, as well as all the cruise leaders and research scientists for collection of the survey data. This study was part of the EUfunded project FAIR-PL98-4122, 'An operational model of the effects of stock structure and spatio-temporal factors on recruitment (STEREO)', and was supported by the Icelandic Research Council and the Ministry of Fisheries.

\section{LITERATURE CITED}

Astthorsson OS, Gislasson A (1995) Long-term changes in zooplankton biomass in Icelandic waters in spring. ICES J Mar Sci Symp 52:657-668

Astthorsson OS, Hallgrimsson I, Jonsson GS (1983) Variations in zooplankton densitites in Icelandic waters in spring during the years 1961-1982. Rit Fiskideildar (J Mar Res Inst Reykjavik) 7(2):73-113

Begg GA, Marteinsdottir G (2000) Spawning origins of pelagic juvenile cod (Gadus morhua) inferred from spatially explicit age distributions: potential influences on year-class strength and recruitment. Mar Ecol Progr Ser 202:193-217

Begg GA, Marteinsdottir G (2002a) Environmental and stock effects on spatial distribution and abundance of mature cod Gadus morhua. Mar Ecol Prog Ser 229:233-244

Begg GA, Marteinsdottir G (2002b) Spatial and temporal partitioning of spawning stock biomass: effects of fishing on the composition of spawners. Fish Res (in press)

Begg GA, Marteinsdottir G (2002c). Environmental and stock effects on spawning origins and recruitment of cod Gadus morhua. Mar Ecol Prog Ser 229:245-262

Begg GA, Hare JA, Sheehan DD (1999) The role of life history parameters as indicators of stock structure. Fish Res 43: 141-163

Buzeta MI, Waiwood KG (1982) Fecundity of Atlantic cod (Gadus morhua) in the southwestern Gulf of St. Lawrence. Can Tech Rep Fish Aquat Sci 1110

Cardinale M, Arrhenius F (2000a) The influence of stock structure and environmental conditions on the recruitment process of Baltic cod estimated using a generalized additive model. Can J Fish Aquat Sci 57:2402-2409

Cardinale M, Arrhenius F (2000b) The relationship between stock and recruitment: are the assumptions valid? Mar Ecol Prog Ser 196:305-309

Cardinale M, Modin J (1999) Changes in size-at-maturity of Baltic cod (Gadus morhua) during a period of large variations in stock size and environmental conditions. Fish Res 41:285-295

Chambers RC (1997) Environmental influences on egg and propagule sizes in marine fishes. In: Chambers RC, Trippel EA (eds) Early life history and recruitment in fish populations. Fish and Fisheries Series 21. Chapman \& Hall, London, p 63-102

Chambers RC, Waiwood KG (1996) Maternal and seasonal differences in egg sizes and spawning characteristics of captive Atlantic cod, Gadus morhua. Can J Fish Aquat Sci 53:1986-2003

Coombs SH (1981) A density-gradient column for determining the specific gravity of fish eggs, with particular reference to eggs of the mackerel Scomber scombrus. Mar Biol 63:101-106

Godø OR, Moksness E (1987) Growth and maturation of Norwegian coastal cod and northeast Arctic cod under different conditions. Fish Res 5:235-242

Hislop JRG, Bell MA (1987) Observations on the size, dry weight and energy content of the eggs of some demersal fish species from British marine waters. J Fish Biol 31:1-20

Holdway DA, Beamish FWH (1985) The effect of growth rate, size and season on oocyte development and maturity of Atlantic cod (Gadus morhua L.). J Exp Mar Biol Ecol 85:3-19

Jakobsson J (1992) Recent variability in the fisheries of the North Atlantic. ICES Mar Sci Symp 195:291-315

Joakimsson G (1969) Fruchtbarkeitsbestimmungen in Kabeljau, Schellfisch und Hering in isländischen Gewässern. Kieler Meeresforsch 25:172-189 
Jørgensen T (1990) Long term changes in age at sexual maturity of Northeast Arctic cod (Gadus morhua L.). J Cons Int Explor Mer 46:235-248

Kjesbu OS (1989) The spawning activity of cod, Gadus morhua L. J Fish Biol 34:195-206

Kjesbu OS, Witthames PR, Solemdal P, Greer Walker M (1990) Ovulatory rhythm and a method to determine the stage of spawning in Atlantic cod (Gadus morhua L.). Can J Fish Aquat Sci 47:1185-1193

Kjesbu OS, Klungsoyr J, Kryvi H, Witthames PR, Greer Walker M (1991) Fecundity, atresia, and egg size of captive Atlantic cod (Gadus morhua) in relation to proximate body composition. Can J Fish Aquat Sci 48:2333-2343

Kjesbu OS, Kryvi H, Sundby S, Solemdal P (1992) Buoyancy variations in eggs of Atlantic cod (Gadus morhua L.) in relation to chorion thickness and egg size: theory and observations. J Fish Biol 41:581-599

Kjesbu OS, Witthames PR, Solemdal P, Greer Walker M (1998) Temporal variations in the fecundity of ArctoNorwegian cod (Gadus morhua) in response to natural changes in food and temperature. J Sea Res 40:303-321

Knutsen GM, Tilseth S (1985) Growth, development, and feeding success of Atlantic cod larvae Gadus morhua related to egg size. Trans Am Fish Soc 114:507-511

Kraus G, Müller A, Trella K, Köster FW (1997) Fecundity of Baltic cod: temporal and spatial variation. J Fish Biol 56: 1327-1341

Lambert Y, Dutil JD (1997a) Can simple condition indices be used to monitor and quantify seasonal changes in the energy reserves of Atlantic cod (Gadus morhua)? Can J Fish Aquat Sci 54(Suppl 1):104-112

Lambert Y, Dutil JD (1997b) Condition and energy reserves of Atlantic cod (Gadus morhua) during the collapse of the northern Gulf of St. Lawrence stock. Can J Fish Aquat Sci 54:2388-2400

Lambert Y, Dutil JD (2000) Energetic consequences of reproduction in Atlantic cod (Gadus morhua) in relation to spawning level of somatic energy reserves. Can J Fish Aquat Sci 57:815-825

MacKenzie BR, Tomkievicz J, Koester F, Nissling A (1998) Quantifying and disaggregating in spawner effect: incorporating stock structure, spatial distribution and female influence into estimates of annual population egg production. ICES CM 1998/BB:11

Malmberg SA, Kristmannsson SS (1992) Hydrographic conditions in Icelandic waters, 1980-1989. ICES Mar Sci Symp (Act Symp) 195:76-92

Marshall CT, Kjesbu OS, Yaragina NA, Solemdal P, Ulltang Ø (1998) Is spawner biomass a sensitive measure of the reproductive and recruitment potential of Northeast Arctic cod? Can J Fish Aquat Sci 55:1766-1783

Marshall CT, Kjesbu OS, Thorsen A, Solemdal P (1999) Spawner quality effects on two measures of reproductive potential: have we been counting our eggs before they've hatched? ICES CM 1999/Y:07

Marshall CT, Yaragina NA, Adlandsvik B, Dolgov AV (2000) Reconstructing the stock-recruit relationship for Northeast Arctic cod using a bioenergetic index of reproductive potential. Can J Fish Aquat Sci 57:2433-2442

Marteinsdottir G, Steinarsson A (1998) Maternal influence on the size and viability of Iceland cod Gadus morhua eggs and larvae. J Fish Biol 52:1241-1258

Marteinsdottir G, Thorarinsson K (1998) Improving the stockrecruitment relationship in Icelandic cod (Gadus morhua) by including age diversity of spawners. Can J Fish Aquat Sci 55:1372-1377

Marteinsdottir G, Gudmundsdottir A, Thorsteinsson V, Ste- fánsson G (2000a) Spatial variation in abundance, size composition and viable egg production of spawning cod (Gadus morhua L.) in Icelandic waters. ICES J Mar Sci 57: $824-830$

Marteinsdottir G, Gunnarsson B, Suthers IM (2000b) Spatial variation in hatch date distributions and origin of pelagic juvenile cod in Icelandic waters. ICES J Mar Sci 57: 1184-1197

MathSoft (1998) S-PLUS 5 for Unix Guide to Statistics. Data Analysis Products Division, MathSoft, Seattle, WA

May AW (1967) Fecundity of Atlantic cod. J Fish Res Bd Can 24:1531-1550

Miller TJ, Herra T, Leggett WC (1995) An individual-based analysis of the variability of eggs and their newly hatched larvae of Atlantic cod (Gadus morhua) on the Scotian Shelf. Can J Fish Aquat Sci 52:1083-1093

Murawski SA, Rago PJ, Trippel EA (1999) Impacts of demographic variation in spawning success on reference points for fishery management. In: Restrepo VR (ed) Proc 5th Nat NMFS Stock Assessment Workshop: providing scientific advice to implement the precautionary approach under the Magnuson-Stevens Fishery Conservation and Management Act. NOAA Tech Memo NMFS-F/SPO-40, p 77-85

Nissling A, Larsson R, Vallin L, Frohlund K (1998) Assessment of egg and larval viability in cod, Gadus morhua: methods and results from an experimental study. Fish Res 38: 169-186

O'Brien L (1999) Factors influencing the rate of sexual maturity and the effect on spawning stock for Georges Bank and Gulf of Maine Atlantic cod Gadus morhua stocks. J Northw Atl Fish Sci 25:179-203

Olafsson J (1985) Recruitment of Icelandic haddock and cod in relation to variability in the physical environment. ICES CM Q:59

Oosthuzien E, Daan N (1974) Egg fecundity and maturity of North Sea cod, Gadus morhua. Neth J Sea Res 8:378-397

Pálsson OK, Jonsson E, Schopka SA, Stefánsson G, Steinarsson BAE (1989) Icelandic groundfish survey data used to improve precision in stock assessments. J Northw Atl Fish Sci 9:53-72

Pentilla J, Dery LM (1988) Age determination methods for Northwest Atlantic species. NOAA Tech. Rep. NMFS 72: $37-40$

Pepin P, Orr DC, Anderson JT (1997) Time to hatch and larval size in relation to temperature and egg size in Atlantic cod (Gadus morhua). Can J Fish Aquat Sci 54(Suppl 1):2-10

Pinhorn AT (1984) Temporal and spatial variation in fecundity of Atlantic cod (Gadus morhua) in Newfoundland waters. J Northw Atl Fish Sci 5:161-170

Powles PM (1958) Studies on reproduciton and feeding of Atlantic cod (Gadus callarias L.) in the southwestern Gulf of St. Lawrence. J Fish Res Bd Canada 15:1383-1402

Rijnsdorp AD, Daan N, van Beek FA, Heessen HJL (1991) Reproductive variability in North Sea plaice, sole, and cod. J Cons Int Explor Mer 47:352-375

Schopka SA (1971) Vergleichende Untersuchungen zur Fortpflanzungsrate bei Herings- und Kabeljaupopulationen (Clupea harengus L. und Gadus morhua L.). Sonderdruck aus Bd 22(1):31-79

Scott B, Marteinsdottir G, Wright P (1999) Potential effects of maternal factors on spawning stock-recruitment relationships under varying fishing pressure. Can J Fish Aquat Sci 56:1882-1890

Serchuk FM, Grosslein MD, Lough RG, Mountain DG, O'Brien L (1994) Fishery and environmental factors affecting trends and fluctuations in the Georges Bank and Gulf 
of Maine Atlantic cod stocks: an overview. ICES Mar Sci Symp 198:77-109

Sokal RR, Rohlf FJ (1995) Biometry: the principles and practice of statistics in biological research, 3rd edn. WH Freeman, New York

Solemdal P (1997) Maternal effects - a link between the past and the future. J Sea Res 37:213-227

Solemdal P, Bergh Ø, Finn RN, Fyhn HJ and 6 others (1992) The effects of maternal status of Arcto-Norwegian cod on egg quality and vitality of early larvae. II. Preliminary results of the experiment in 1992. ICES CM 1992/G:79

Solemdal P, Bergh Ø, Dahle G, Falk-Petersen IB and 10 others (1993) Size of spawning ARCTO-Norwegian cod (Gadus morhua L.) and the effects on their eggs and early larvae. ICES CM 1993/G:41

Solemdal P, Kjesbu OS, Fonn M (1995) Egg mortality in recruit- and repeat-spawning cod-an experimental study. ICES CM 1995/G:35

Stearns SC, Crandall RE (1984) Plasticity for age and size at sexual maturity: a life history response to unavoidable stress. In: Potts GW, Wooton RJ (eds) Fish reproduction: strategies and tactics. Academic Press, London, p 13-33

Swartzman G, Silverman E, Williamson N (1995) Relating trends in walleye pollock (Theragra chalcogramma) abundance in the Bering Sea to environmental factors. Can J Fish Aquat Sci 52:369-380

Thordardottir T (1986) Timing and duration of spring bloom-

Editorial responsibility: Otto Kinne (Editor),

Oldendorf/Luhe, Germany ing south and southwest of Iceland. In Skreslet S, Series G (eds) The role of freshwater outflow in coastal marine ecosystems. Ecological Sciences, Vol 7. Springer-Verlag, Berlin, p 345-360

Trippel EA (1998) Egg size and viability and seasonal offspring production of young Atlantic cod. Trans Am Fish Soc 127:339-359

Trippel EA (1999) Estimation of stock reproductive potential: history and challenges for Canadian Atlantic gadoid stock assessments. J Northw Atl Fish Sci 25:61-81

Trippel EA, Kjesbu OS, Solemdal P (1997a) Effects of adult age and size structure on reproductive output in marine fishes. In: Chambers RC, Trippel EA (eds) Early life history and recruitment in fish populations. Fish and Fisheries Series 21. Chapman \& Hall, London, p 31-62

Trippel EA, Morgan MJ, Frechet A, Rollet C, Sinclair A, Annand C, Beanlands D, Brown L (1997b) Changes in age and length at sexual maturity of northwest Atlantic cod, haddock and pollock stocks, 1972-1995. Can Tech Rep Fish Aquat Sci 2157:1-132

Vallin L, Nissling A (2000) Maternal effects on egg size and egg buoyancy of Baltic cod, Gadus mohua: implications for stock structure effects on recruitment. Fish Res 49: 21-37

Van der Meeren T, Jorstad KE (1994) Growth and survival of cod larvae (Gadus morhua L.): comparative enclosure studies of Northeast Arctic cod and coastal western Norway. ICES Mar Sci Symp 198:633-645

Submitted: June 20, 2001; Accepted: February 21, 2002

Proofs received from author(s): May 17, 2002 